\title{
Milton Friedman and U.K. Economic Policy: 1938-1979
}

Edward Nelson

\begin{abstract}
Milton Friedman's publications and commentaries became the subject of enormous publicity and scrutiny in the United Kingdom. This paper analyzes the interaction of Milton Friedman and U.K. economic policy from 1938 to 1979. The period under study is separated into four subperiods: 1938-46, 1946-59, 1959-70, and 1970-79. For each of these subperiods, the author considers Friedman's observations on, and role in, key developments in U.K. monetary policy and in general U.K. economic policy. (JEL E31, E32, E51, E52)
\end{abstract}

Federal Reserve Bank of St. Louis Review, September/October 2009, 91(5, Part 2), pp. 465-506.

\section{INTRODUCTION}

W

hen invited to comment on economic developments in the United Kingdom, Milton Friedman frequently prefaced his remarks with a caveat. Thus in 1964 he testified, "I have not followed in detail the current circumstances of the British economy." 1 And much later in 2005, Friedman likewise stated, "I have no expertise on recent British experience." But it was rare for him to confine his remarks to this caveat. U.K. economic conditions were an unrelenting source of interest to Friedman, a selfdescribed "life-long student of the monetary and economic experience" of the United Kingdom, ${ }^{2}$ who, as we will see, was as early as 1943 citing speeches by contemporary U.K. policymakers and drawing on U.K. economic data.

In time, Friedman's influence on U.K. economic discussion would become so pervasive

\footnotetext{
1 From the question-and-answer portion of Friedman's March 3, 1964, testimony, in Committee on Banking and Currency (1964, p. 1144).

2 Friedman (1980a, p. 55).
}

that he was part of the U.K. economic policy debate whether he liked it or not. The fact is that Friedman's celebrity was proportionately much greater in the United Kingdom than in the United States. The January 1977 issue of the U.K. business magazine Management Today referred to the "present controversy, more acute in Britain than anywhere else, over the teachings of Professor Milton Friedman"; and even in 2001, long after the peak of his fame, the London Independent newspaper described Friedman as "one of the few economists to have become a household name" (Independent, August 28, 2001). ${ }^{3}$

Friedman's emphasis on the effects of monetary policy, and his opposition to state intervention in the economy, guaranteed that he would be classified as a marginal figure-if not ignored outright-by U.K. academic and policy circles in the early postwar period. Friedman discovered this for himself during spells in the United

\footnotetext{
3 A bibliographical appendix gives details for newspaper and periodical articles cited in this paper. Sources in the appendix are arranged chronologically.
}

The author is indebted to Charles Goodhart, David Laidler, Alvin Marty, Anna Schwartz, and Gloria Valentine for answers to many inquiries on the subject matter of this paper. For help on specific issues, he thanks Terry Arthur, Anna Burke, Elizabeth Ennion, Robert Leeson, Mervyn Lewis, and Louise North. The author also made considerable use of the services of the Federal Reserve Bank of St. Louis Research Library in the course of obtaining material for this paper; the library staff who have helped include Adrienne Brennecke, Kathy Cosgrove, Barbara Dean, Julia Seiter, Katrina Stierholz, and Anna Xiao. Luke Shimek and Faith Weller provided research assistance.

(c) 2009, The Federal Reserve Bank of St. Louis. The views expressed in this article are those of the author(s) and do not necessarily reflect the views of the Federal Reserve System, the Board of Governors, or the regional Federal Reserve Banks. Articles may be reprinted, reproduced, published, distributed, displayed, and transmitted in their entirety if copyright notice, author name(s), and full citation are included. Abstracts, synopses, and other derivative works may be made only with prior written permission of the Federal Reserve Bank of St. Louis. 
Kingdom in the early 1950s. The marginal status of Friedman and his positions persisted, with short-lived exceptional periods, well into the 1960s. But from the late 1960s and afterward, Friedman's positions, while still encountering resistance at the policymaking level, became the subject of enormous publicity and scrutiny in the United Kingdom. The control of inflation was at the center of U.K. political debate from 1968 to 1979, dominating other policy issues during that period in a way that it did not in the United States, where Vietnam, Watergate, and superpower relations competed with, and frequently superseded, inflation in prominence.

Particularly over this most intense period, Friedman made interventions himself on the U.K. scene. He provided commentary on British policy developments during U.K. visits as well as by long distance from the United States. Friedman's U.K. contributions also included some fundamental statements of his positions-most notably his lecture, "The Counter-Revolution in Monetary Theory" (Friedman, 1970a). This lecture, delivered at the University of London in September 1970, was treated by Bernanke (2004) as the most representative statement of Friedman's views on monetary matters and was what Friedman cited as the place for a list of "some fundamental propositions of monetarism."4

Friedman's contributions to the U.K. scene included several rebuttals to criticisms of his research findings on monetary relations. In 1970 he had stated, "I am so happily blessed with critics that I have been forced to adopt the general rule of not replying to them." 5 In light of this policy, the extent to which critics based in the United Kingdom were able to smoke him out, and provoke a direct, published rejoinder from Friedman, is impressive: Nicholas Kaldor in the 1970s, Frank Hahn and Robert Neild in the 1980s, David Hendry and Neil Ericsson in the 1990s.

The emergence of the United Kingdom as a major battleground for the debate on Friedman's views, and particularly on Friedman's version of monetarism, was amplified by the positions of

\footnotetext{
4 Friedman, quoted in Snowdon, Vane, and Wynarczyk (1994, p. 174).

5 Friedman (1970b, p. 326).
}

the leading Keynesians in the United Kingdom. As Cobham (1984, p. 160) observes, "British Keynesianism has traditionally been more 'extreme,' more 'hardline,' than that prevalent for example in North America." In particular, in the first several postwar decades, U.K. Keynesians were more inclined than their U.S. counterparts to dismiss altogether the importance of monetary policy. The United Kingdom featured a greater and much longer-lasting "nonmonetary," or "money does not matter," brand of Keynesianism. That this viewpoint was the establishment position in U.K. economics until the 1980s is reflected in the names of those U.K. economists leading the opposition to Friedman and monetarism. Among them were an array of knights and barons: Sir Roy Harrod, Sir John Hicks, Sir Alec Cairncross, Lord Kahn, Lord Kaldor, and Lord Balogh. ${ }^{6}$

Because Keynesianism took a more militant form in the United Kingdom than in the United States, the U.K. debates on monetary policy were more fundamental, and their outcome produced a greater break in the direction of U.K. policymaking.

This brings me to the subject matter of this paper, which is the interaction of Friedman and U.K. economic policy over the period from 1938 to 1979. An obstacle to carrying out a study of this kind is that Friedman never published a single, definitive account encapsulating his views on U.K. developments. True, Friedman and Anna Schwartz wrote a detailed study of U.K. monetary relations, their Monetary Trends (Friedman and Schwartz, 1982). But while Friedman once made a shorthand reference to this book as a study of "U.K. monetary history" (Wall Street Journal, February 12, 1987), the volume was not, in fact, a U.K. counterpart to Friedman and Schwartz's (1963) A Monetary History of the United States. Rather, its focus was on the quantitative analysis of longer-term economic relations, with Friedman and Schwartz (1982, p. 605) acknowledging, "We have not made a similarly exhaustive study of United Kingdom monetary history." Monetary Trends does contain along the way many observations on U.K. develop-

\footnotetext{
6 After 1979, as governments more sympathetic to monetarism took charge of the honors system, the tables were turned, and some of the U.K. monetarist writers received titles: Sir Alan Walters, Sir Samuel Brittan, Sir James Ball, Lord Griffiths, and so on.
} 
ments that are relevant to the present paper and that are incorporated into my discussion. But the book is not a sufficient statistic when it comes to studying Friedman's views on U.K. economic developments; it does not contain most of Friedman's observations on the year-to-year course of U.K. economic policy. For that, one must turn to other places.

And, for a comprehensive account, this means looking in a lot of places. Friedman's remarks are widely dispersed across time and location. Not only his writings but also many interviews are relevant, as they frequently contain, in the words of Friedman and Schwartz (1982, p. 623), "illuminating side comments" on U.K. economic matters. And of those interviews Friedman gave in which the United Kingdom was the major topic, many were in U.K. newspapers that have been neither indexed nor electronically archived.

At first sight, the multiplicity of sources might not seem too troublesome: Perhaps, it could be argued, there are only a few basic Friedman references, the remainder being repetition and propagation of his key work. It is true that in the course of countless lectures, writings, and interviews, Friedman repeated himself on every dimension: on the points he made, the historical examples he cited, the analogies he drew, the anecdotes he related. Putting aside actual reprints, the repetition is most evident in the considerable number of his writings that include extended quotations from previous works. Even the largely new Friedman-Schwartz Monetary Trends opened its concluding chapter with a lengthy excerpt from a 1972 Friedman paper. And in his 1992 book, Money Mischief, Friedman only makes it through six lines of text before deploying a quotation from an earlier book of his. On one occasion, Friedman, using a stop-me-before-I-kill form of words, acknowledged this practice: "I'm sorry to quote myself all the time, but I can't help it" (Fortune, March 19, 1984).

Notwithstanding the heavy repetition, there is usually some marginal contribution-perhaps an added observation or an update or qualification to previous analysis-even in those works of Friedman that drew most heavily on his previous writings. In other words, while Friedman repeated himself often, he rarely repeated himself completely. It would, furthermore, be misguided to think that Friedman's most relevant observations on a particular subject appeared in his most prominent journal publications or in his most widely cited articles. If anything, the opposite is the case. This reflects the pattern summarized by Johnson (1974, p. 346) as Friedman's “life-long habit of scattering his new empirical results and ideas in unlikely places." Friedman's tendency to "fractionate" his written output by spreading it across an enormous variety of outlets means that, to obtain the full picture, one has to reconstitute the record from this very wide base.

I have carried out such a reconstitution for this study. The deployment of extensive source material is a principal contribution of this paper. The research here is based on an analysis of Friedman's publications, including many articles neither appearing in his book collections nor available electronically; his op-ed contributions; his published interviews in newspapers, magazines, and journals, as well as my own meetings with him; and much unpublished material. I have built a database of Friedman's public statements, based on my extensive microfilm searches, on physical inspection of hard copies of newspapers, on information from search services offered by companies and by newspapers, and on searches of newspaper and other databases that are publicly electronically archived. My search through Friedman correspondence included examination of samples from the Hoover Institution Archives' catalogued correspondence and of correspondence yet to be catalogued by the Archives, ${ }^{7}$ and my own correspondence with Friedman from 1991 to 2006.

Also, crucially, I draw extensively on material (both correspondence and memoranda) provided to me by Anna Schwartz from her own files. ${ }^{8}$ As

\footnotetext{
7 I am indebted to Friedman's secretary, Gloria Valentine, for fulfilling my requests for information about as-yet-uncatalogued Friedman files before her retirement in 2007, as well as answering many inquiries from me on the subject matter of this paper.

8 As well as for the generous access she granted me to this material, I am indebted to Anna Schwartz for answering numerous inquiries on the subject matter of this paper. This includes responses to specific inquiries I made during the course of writing this paper and, more generally, information conveyed in assorted correspondence, conversations, and meetings with me from 1991 onward.
} 
well as (obviously) covering much of her work with Friedman on monetary policy generally, these files cover such U.K.-relevant material as Friedman's lecture to the London School of Economics in May 1952. ${ }^{9}$ I use Congressional testimony and submissions by Friedman, including several items not included in his comprehensive published bibliographies. I also draw on transcripts of television interviews Friedman gave in the United States and the United Kingdom in the 1960s and 1970s that have been infrequently, if ever previously, cited.

The remaining discussion in this paper is divided into chronological segments. For each segment, I consider the main U.K. economic events and Friedman's interaction with them and then, particular issues in each period. Brief concluding remarks and a bibliographical appendix complete the paper.

\section{8-1946}

\section{Events}

In 1938, Milton Friedman, then age 25, was based in New York City at the National Bureau of Economic Research (NBER), where he was working primarily on completion of his dissertation. His dissertation work came under the umbrella of what would subsequently be called "microeconomics," but Friedman also kept up with the literature on monetary policy and business cycles. It was in this connection that, as he told Brian Snowdon and Howard Vane, "I bought [The General Theory of Employment, Interest and Money (Keynes, 1936)] in 1938 and paid a dollar and eighty cents for it."10

Friedman's recollection was that he was "if anything[,] somewhat hostile" to the General Theory (Friedman 1972a, p. 936), and that he was influenced by the fact that among older economists there had been "a good deal of skepticism and dissatisfaction" in response to the book (Friedman,

\footnotetext{
9 Where known, I also identify, for the Friedman-Schwartz correspondence, the location of the corresponding copy of the material in the Friedman papers at the Hoover Archives.

${ }^{10}$ In Snowdon and Vane (1997, p. 195).
}

1982a, p. 9). Moreover, of the younger economists closest to Friedman, Arthur Burns expressed reservations about the novelty of the General Theory, later contending that he had favored expansionary measures "as early as 1930, before Keynes' theories were known." 11

Unlike the initial skeptics, Friedman did not deny the novelty of Keynes's theoretical contribution. The General Theory's explanation for the Depression and its rationalization for fiscal expansion, Friedman would conclude, were not merely restatements of preexisting ideas; he would credit Keynes with a "rigorous and sophisticated analysis" (Friedman, 1968b, p. 1) that provided "a new, bold, and imaginative hypothesis" (Friedman 1972a, p. 908).

Friedman did share the concern that Keynes's book would be seen as giving the green light for a permanent increase in the size of government. To the critics, Keynes was providing a respectable theoretical rationalization for extensive government intervention, through his depiction of the income-expanding effects of government purchases and his characterization of private investment demand as destabilizing. In addition, Friedman later argued that the underemploymentequilibrium argument in the General Theory was "highly congenial to the opponents of the market system" (Friedman and Schwartz, 1982, p. 43). Friedman's verdict at the end of the 1970s was that the idea that "deficits...were a way of expanding the economy" led to a "tremendous growth in government spending” (May 17, 1979, testimony, in Committee on the Judiciary, 1980, p. 149).

These misgivings about the perceived policy implications of the General Theory reflected Friedman's free-market, small-government attitudes, already entrenched by 1938. Friedman assessed in retrospect that "I was mildly socialistic" before graduate study (Newsweek, June 15, 1998). But he had been converted to free-market attitudes during the portion of his graduate studies that he took at the University of Chicago ${ }^{12}$

\footnotetext{
${ }^{11}$ Burns, October 2, 1975, testimony in Committee on the Budget (1975, p. 170). Friedman described Burns as "really my mentor" during Friedman's early career (C-SPAN, November 20, 1994).

${ }^{12}$ For example, Friedman (1976a, p. xxi) acknowledged, "I was influenced in this direction by my teachers at the University of Chicago."
} 
"an excellent Department of Economics, I think the greatest in the country, even before I was there."13

What Friedman in 1938 called "this damn European situation"14 led to the United Kingdom going to war in September 1939. Following the United States' entry into World War II in 1941, Friedman joined the U.S. Treasury. He later said that his Treasury colleagues and superiors saw him as a "starry-eyed theorist." 15 This being the case, it was as a Keynesian theorist, for Friedman had largely accepted the theoretical contribution of the General Theory. In particular, he embraced its skeptical perspective on monetary policy. Friedman acknowledged in a television interview in 1994 that "when I was at the Treasury, I was essentially a Keynesian, as I believed that the way to control inflation was by controlling government spending. I paid very little attention to money" (C-SPAN, November 20, 1994).

The Keynesian perspective is so clear in Friedman's early 1940s writings that monetarists such as Laidler (2003) have marveled at the contrast with Friedman's later work. Friedman expressed a similar sense of surprise when looking at the 1940s work from the vantage point of three decades later. "In a note on the inflationary gap that I published in 1942," Friedman said in a November 1971 talk (Friedman, 1972b, p. 183), "I never mentioned the quantity of money or monetary factors at all!”

The Keynesian position that there was a region where money and income had a very loose relationship with one another was, to Friedman, seemingly confirmed by his look at data. His (1943) paper on inflation, written while at the Treasury,

\footnotetext{
${ }^{13}$ Milton Friedman Speaks, Episode 8, p. 30 of transcript. Milton Friedman Speaks was the name given to a series of Friedman talks in the United States videotaped over 1977-78 and used to promote interest in a projected television series for Friedman; see Friedman and Friedman (1998, pp. 477-78, 604). The series was released on a limited basis on videotape, accompanied by official transcripts, in 1980, and was more recently repackaged as a commercially available DVD set. References made in this paper are generally to the transcripts, but all the quotations from the transcripts also appear on the DVD releases.

${ }^{14}$ March 17, 1938, letter from Milton Friedman to Rose Friedman, quoted in Friedman and Friedman (1998, p. 77).

${ }^{15}$ For example, in Newsweek, July 24, 1978.
}

plotted growth rates of nominal money and nominal income for the United States for 1899-1929; the plot led to Friedman's judgment that the relationship was "extremely unstable."16 This judgment seems untenable. Simple inspection of the scatterplot in Friedman's paper (Friedman, 1943 , p. 121) indicates that the money growthincome growth relationship is clearly positive and reasonably tight by the standards of rate-ofchange data.

Friedman also embraced some of Keynes's post-General Theory ideas, notably those in Keynes's How to Pay for the War (1940). Friedman's contribution to "inflationary gap" analysis was in this tradition. This work (Friedman, 1942,1943 ) revealed a close following of U.K. developments. Specifically, Friedman (1943) discussed "recent English discussion of fiscal policy [that] has centered on the so-called 'inflationary gap,"” discussed U.K. gap estimates made by British economist Frank Paish, and cited a 1943 House of Commons speech by the Chancellor of the Exchequer, Kingsley Wood, a speech known to have been drafted by Keynes (see Samuelson, 1946).

"Inflationary gap" analysis had in common with Friedman's later work the portrayal of inflation as demand inflation. The details of how inflation emerged, however, were different in his 1940s' analysis. Inflation in this analysis was seen as serving to equalize the nominal value of potential output and the nominal volume of aggregate spending. Potential output was assumed to have a physical ceiling, so that price change took up all the excess spending above this maximum. There was, in contrast to later Keynesian and monetarist work, no allowance for "overfull employment." Reflecting his later use of the overfull employment concept, Friedman would say in 1972, "I think people are wrong in supposing that there is a rigid ceiling on output such that further increases in real output are impossible...It is possible to have overemployment as well as underemployment."17

\footnotetext{
${ }^{16}$ Friedman (1943, p. 119). Friedman contrasted this with what he called the "considerably more regular" empirical relation between consumption and income, which supported Keynesian theory (1943, p. 120).

${ }^{17}$ Friedman (1973a, p. 35).
} 
In postwar work, Friedman and others would accordingly distinguish carefully between potential and maximum output. ${ }^{18}$ In particular, the notion that output could temporarily exceed potential, and unemployment fall below its natural rate, was a contribution of Friedman's natural rate hypothesis (e.g., 1968b, 1977a). Nevertheless, the concepts of positive output gaps, and associated overfull employment, were innovations neither of Friedman nor of the Phillips curve literature; they were in place earlier than the 1950s and 1960s. The possibility that overfull employment could occur was specifically embodied in the U.K. policymaking framework by the late 1940s.

"During World War II," Friedman later recalled, "governments everywhere had largely assumed control of the economy. And it was simply almost taken for granted that they would have to continue to do so in the postwar period."19 The Attlee government was elected in the U.K. general election of July 1945. Friedman noted, "In Britain, the Labour Party's postwar victory over Winston Churchill spelled a commitment to central planning” (Newsweek, July 14, 1975).

\section{Issues}

\section{Nationalization and Central Planning.}

Friedman observed that the postwar shift to greater government economic control had been justified on efficiency grounds: It was believed "that centralized and comprehensive economic planning and control by government is an essential requisite for economic development" (Friedman, 1958a, p. 505). He noted that, in particular, nationalization of industries was motivated by this consideration (The Listener, April 27, 1978). The Attlee government used the efficiency argument when implementing a broad nationalization program after it came to power.

This nationalization program was believed to be appealing to U.K. electors, to judge by the notice of their plans that leading Labour politi-

\footnotetext{
${ }^{18}$ Friedman would still believe that there was a physical ceiling on output (see the expositions of his plucking model in Friedman 1964b, 1993), but he no longer treated this ceiling as synonymous with the natural level of output.

${ }^{19}$ Quoted in Levy (1992).
}

cians gave in the months approaching the election. Stafford Cripps, later Chancellor of the Exchequer, said, "We must replace the libertinism of private enterprise by a planned system of economy which calls for a considerable measure of state control and ownership." As did many in the West, Cripps cited the Soviet Union as a successful economic model: "In Russia you have a State-planned and controlled industry, and I cite this as an example to show that some form of centralized planning and control helps and does not retard efficient production and full employment" (NewsChronicle, December 18, 1944).

The nationalizations undertaken by the Attlee government (1945-51) encompassed mining, communications, the railway system, and steel. ${ }^{20}$ Friedman had anticipated that a still more comprehensive nationalization scheme would be carried out. He observed in 1972 of the late 1940s, "If you had asked us then about the health of capitalism and free enterprise 25 years later, I think we would have said it would be closer to its deathbed than it actually is now." 21

In fact, Friedman's Capitalism and Freedom (1962a) contains remarks to the effect that he thought that in the United Kingdom the move toward greater government intervention had peaked even before the Attlee government left office. In particular, Friedman took comfort from the fact that central planning, as opposed to nationalization, had not endured in Western economies beyond the 1940s. The detailed direction of resources, public and private, had been foreshadowed by the Attlee government; as Friedman noted, "immediately after World War II, it was thought that the government was going to get involved, especially in Britain...in central economic planning on a large scale." 22 Efforts to replace the price system with government direction of allocation decisions had, he argued, faltered and led to socialism peaking in the United Kingdom in 1948 (Vision, April 1972). Friedman

\footnotetext{
${ }^{20}$ See Childs (2006, p. 14) for a tabulation of the Attlee government's nationalizations.

${ }^{21}$ Friedman speaking in Business and Society Review, Spring 1972; reprinted in Friedman (1975a, p. 253).

${ }^{22}$ Free to Choose, PBS debate 1980, Episode 3, p. 9 of transcript.
} 
(1962a, p. 11) singled out the fate of the Attlee government's Control of Engagements Order, which, he said, would have meant a directedlabor economy if it had been enforced. The Order was not, in fact, enforced heavily and was then repealed, an event Friedman identified as a "turning point" (Friedman, 1962a, p. 11) when "central planning came to a screeching halt" in the United Kingdom. ${ }^{23}$

But Friedman further revised his opinion in the 1970s: He observed in 1972, "I was much more optimistic in 1962 than was justified by what happened later." 24 Friedman continued to acknowledge that the momentum for planning and nationalization had stalled, noting that "[t]here is less central planning in Britain now than in 1946," 25 but he now judged that this had "diverted...growth [in government] to a different channel" (New York Times, August 13, 1994). Greater government influence on resource allocation, he argued, had instead been achieved via expansion of government spending (including transfer programs) and of regulation (Friedman, 1976c; Friedman and Friedman, 1998, p. 582). This changed perception was reflected in Friedman's descriptions of the U.K. system: Whereas he characterized what was launched in the United Kingdom in the 1940s as "a policy of welfare statism and central planning” (Saturday Evening Post, May/June 1977), Friedman argued that the system evolved into "a socialist and welfare state" (National Review, December 31, 1997).

Cheap Money. Many countries followed "cheap money" policies in World War II and its aftermath; the U.S. case is the subject of Friedman and Schwartz (1963, Chaps. 10 and 11). In the United Kingdom, the postwar "cheap money" policy is associated with the attempt by Chancellor of the Exchequer Hugh Dalton to break with the practice his adviser, John Maynard Keynes, had described as "the unwillingness of most monetary authorities to deal boldly in debts

\footnotetext{
${ }^{23}$ In Business and Society Review, Spring 1972; reprinted in Friedman (1975a, p. 254).

${ }^{24}$ Friedman, October 20, 1972, remarks, in Selden (1975, p. 51).

${ }^{25}$ From Business and Society Review, Spring 1972, reprinted in Friedman (1975a, p. 254).
}

of long term" (Keynes, 1936, p. 207). Although announced by the Attlee government upon its election, the long-term bond program began in earnest in October 1946, several months after Keynes's death. Among the new government bonds created in 1946 was a series of 2.5 percent "irredeemable" securities, that is, securities that might be held indefinitely as a source of interest income; these new long-term securities were unofficially known as "Daltons" or "Dalton consols." By issuing very-low-yield medium- and long-term securities, Dalton attempted to extend the government's existing low interest rate policy to the entire term structure. "We have been gradually conditioning the capital market to a longterm rate of $2 \frac{1}{2} \%$," Dalton observed. “...I am sure that our cheap money policy should continue to be resolutely pressed home" (Financial Times, October 17, 1946).

The U.K. and U.S. authorities' interest in influencing long-term rates rested heavily on the Keynesian position that long-term rates mattered for aggregate demand much more than short rates; this interest was qualified by the consideration that, as Friedman and Schwartz (1963, p. 700) observe, even the sensitivity of demand to longterm rates was not thought to be substantial. Low long-term interest rates were also perceived as contributing to the flexibility of fiscal policy by easing the financing of the national debt. So the extension of the cheap money policy to the long-term market had both Keynesian and debtmanagement motivations.

The Dalton program of October 1946, while involving the creation of new debt instruments, was intended to drive existing longer-term securities' rates down to 2.5 percent too (see, e.g., Hallowell, 1950, p. 41); this contrasted with the rates between 3 percent and 3.5percent prevailing for most of the period since 1932 (Hallowell, 1950, p. 23; Robertson, 1949, p. 22). ${ }^{26}$ Since Bank Rate was left unchanged, the experiment was not making use of the expectations theory of the term structure. On the contrary, the expectations theory

\footnotetext{
${ }^{26}$ When serving as a discussant of Friedman's in 1970, Sir Roy Harrod paraphrased Dalton's rationale for the reduction in the long-term rate as that if "we could run a great war at $3 \%$, we ought to be able to run the peace at $2.5 \%$ " (Harrod, 1971, p. 59).
} 
would suggest that keeping the short rate unchanged tended to work against the success of a policy to reduce long-term rates. From the perspective of the General Theory, however, the approach made some sense: The General Theory saw securities as becoming equivalents of money before their yield became zero; insofar as shortterm interest rates were perceived as already having hit their floor, but long-term rates had not reached their floor, the monetary authorities could carry out operations directly in long-term securities markets to encourage reductions in longerterm rates.

Wilson (1984, p. 76) observes that there were "few British economists in the 1950s and 1960s who advocated control of the money supplyRobertson, Robbins, Paish, Dacey, myself [Thomas Wilson], and one or two others." Among those on this list who were active in the 1940s, Robertson was perhaps the leader and is acknowledged in Friedman and Friedman (1998, p. 247) as an early distinguished skeptic regarding Keynesian economics. That skepticism is evident in Robertson's discussions of the Dalton monetary policy, as Robertson (1949, p. 22) counts himself among those "who dared to question the wisdom of this [1946] further turn of the [cheap money] screw." A fellow critic, Dacey (1947, p. 59) wrote that "it is surprising that Mr. Dalton should have thought it good statesmanship to press rates down further at a time when inflationary forces are only kept in check with the assistance of a formidable administrative apparatus [i.e., price controls].”

Friedman's own later work contained critical observations on the U.K.'s monetary framework during the 1940s. There are many further criticisms implicit in Friedman's descriptions of what monetary policy can and should do. Friedman's framework centered, first and foremost, on the point that "monetary policy is not about interest rates; monetary policy is about the rate of growth of the quantity of money." 27 The Fisher relation provided the only enduring channel by which the central bank could affect interest rates, be they short- or long-term. Monetary policy could exert other, more transitory influences on interest rates,

${ }^{27}$ From Friedman's appearance on Meet the Press, October 24, 1976. but Friedman was skeptical that these influences justified central banks' claims that they could control long-term interest rates (see, e.g., Friedman and Schwartz, 1963, p. 514). Certainly, he believed that a base money injection could produce some temporary downward pressure on long-term rates, both via the standard expectations channel (i.e., via the liquidity effect on current and expected future short rates) and via a portfolio effect on the long-short spread or term premium (see, e.g., his June 1966 memorandum to the Board of Governors, published in Friedman, 1968a, p. 156). But for the central bank to exploit these effects in a way that made the long-term interest rate a policy instrument would require being able to overwhelm the "nonmonetary forces affecting interest rates" 28 as well as the Fisher effect, which showed up in "long-term interest rates much sooner" 29 than in short-term rates and worked in the opposite direction of the liquidity and portfolio effects of the money injection. Moreover, Friedman noted, the sustainability of this policy was doubtful, since for a central bank to "peg a particular interest rate...it must accept whatever happens to other magnitudes affected by the [monetary] base, including the level of inflation" (Wall Street Journal, April 5, 1990).

The Dalton attempt to bring down long-term rates had the temporary appearance of success. Rates on existing long-term securities fell toward the new 2.5 percent baseline. For example, Friedman and Schwartz's (1982, Table 4.9, p. 133) data on "old" consols (i.e., the perpetual-horizon security already being traded before the release of the new, "Dalton" consols) show an average rate of 2.92 percent in 1945 and 2.6 percent in 1946. But the effort to hold down long-term interest rates did prove unsustainable, and in the course of 1947 long-term rates rebounded; Friedman and Schwartz's series shows an average for 1947 of 2.76 percent, rising to 3.21 percent in 1948 . Friedman (1970a, p. 8) observed, "Chancellor Dalton tried to follow the Keynesian policy of keeping interest rates very low. As you all know,

\footnotetext{
${ }^{28}$ From Friedman's October 1965 memorandum to the Board of Governors, published in Friedman (1968a, p. 136).

${ }^{29}$ Friedman (1983, p. 11).
} 
he was unable to do so and had to give up." A few months after Dalton left office, the Financial Times reported, "The attempt to hold the rate of interest on government long-term borrowing at $2 \frac{1}{2} \%$ has now been officially abandoned" (Financial Times, January 3, 1948).

The pressure on the cheap money policy in the United Kingdom was more acute than in the United States because the associated pressure on aggregate demand was one-sided. An interest rate peg can in principle be contractionary in effect, as when the central bank has to withdraw base money to enforce the peg. Friedman and Schwartz (1963, p. 596) find that the U.S. cheap money policy indeed produced deflationary pressure over 1948, and Friedman and Schwartz (1982, p. 76) classify 1948-49 as a business contraction in the United States. No corresponding contractionary episode is evident during the U.K. postwar cheap money period, and Friedman and Schwartz (1982, p. 76) classify 1946-59 as a continuous expansion in the United Kingdom. The U.K. experience consequently corresponded more literally than did the U.S. case to Friedman's summary statement that "the stock of money rose as a result of the cheap-money policies and so did prices, either openly or in whatever disguise." 30

The Dalton policy on long-term interest rates was the first element of the U.K. monetary framework to break under this one-sided pressure; the exchange rate policy was next, with sterling devaluation taking place in 1949. The outbreak of the Korean War in 1950 magnified the pressure on the remaining component of the cheap money policy, namely, the holding of Bank Rate at 2 percent. The Financial Times noted (February 10, 1951): "Both the British and American governments seem determined not to use higher interest rates to combat inflation." This determination contrasted with Friedman's position, which he articulated in 1952 as follows: "The purpose of monetary policy is to maintain price stability, and on some occasions this will call for actions that tend to raise interest

\footnotetext{
${ }^{30}$ May 25, 1959, testimony, in Joint Economic Committee (1959a, p. 607; p. 138 of 1964 reprint).

${ }^{31}$ March 25, 1952, testimony, in Joint Committee on the Economic Report (1952, p. 736).
}

rates." 31 Bank Rate was finally raised by the newly elected Churchill government in November 1951. "No country succeeded in stemming inflation without adopting measures that made it possible to restrain the growth in the stock of money," Friedman observed at the end of the 1950s. "And every country that did hold down the growth in the stock of money succeeded in checking the price rise." 32

\section{6-1959}

\section{Events}

Friedman's first visit to the United Kingdom in 1948, consisting of "two or three days in England, in London," 33 left him convinced that it was being "economically strangled by the law obedience of her citizens" (Friedman, 1962b). Friedman was persuaded by the argument made by George Stigler, with whom he made the trip, that price controls were distorting the United Kingdom to an extent that they were not in France, because of the more-extensive French underground economy. ${ }^{34}$ Price controls had been introduced by the United Kingdom in wartime, Friedman later observed, in an "attempt to suppress the inflation arising from wartime spending, financed largely by increasing the money supply" (Newsweek, November 27, 1972). The Attlee government continued the controls into peacetime. Friedman opposed price controls both as a wartime and a peacetime measure (see his October 6, 1969, testimony in Joint Economic Committee, 1970, pp. 815-16) The peacetime controls in the United Kingdom and on the Continent were, he argued in an early intervention, impeding Europe's economic recovery (New York Times, January 11, 1948).

Other damaging restrictions, Friedman contended, came in the "foreign exchange controls that strangled Western Europe after the war." 35

\footnotetext{
${ }^{32}$ May 25, 1959, testimony, in Joint Economic Committee (1959a, p. 607; p. 138 of 1964 reprint).

${ }^{33}$ Milton Friedman Speaks, Episode 1, p. 9 of transcript.

${ }^{34}$ Friedman (1962b); and Milton Friedman Speaks, Episode 1, p. 9 of transcript.

${ }^{35}$ Friedman (1964a); p. 78 of 1969 reprint.
} 
Foreign exchange controls were not initially emphasized by Friedman in the 1940s, when his focus was on price control. "I wrote my first article [on exchange controls] in 1950," Friedman later recalled, "when I was in France in connection with the Common Market arrangements" (Jerusalem Post, November 6, 1987). For the United Kingdom, Friedman's position, maintained from the early 1950s, was that exchange controls had such a depressing effect on the level of the pound sterling that if the U.K. authorities floated the pound and maintained exchange controls, the pound would tend to depreciate, whereas if they floated simultaneously with the removal of exchange controls, the pound would appreciate (Friedman, 1953b; Friedman and Schwartz, 1982a, pp. 290-94). This conjecture was borne out when the pound appreciated after the abolition of exchange controls in 1979. Friedman criticized the exchange controls on economic grounds, but "entirely aside" from their economic aspects, he opposed them on grounds of "human freedom."36 It violated the "free market in ideas," he said in 1977, "if a country, as Great Britain did immediately after the war, has exchange controls under which no citizen of Britain may buy a foreign book unless he got authorization from the Bank of England."37

Even by the early 1950s, the United Kingdom had acquired a basket-case image in the United States for its postwar performance, with extensive economic aid by the United States to the United Kingdom highlighting the problem. "When people say, 'Well, American aid bailed Germany out,' I add that American aid also bailed Britain out," Friedman later observed. "The amount we gave to Britain in the British-American loan was far greater than anything Germany got" (Saturday Evening Post, May/June 1977).

The United Kingdom was also a recipient of aid from the United States via the Marshall Plan. Friedman contended that "Europe would have recovered with or without the Marshall Plan," and opposed the Plan at the time and in retrospect (Friedman, 1982a, pp. 32-33). He argued that the

\footnotetext{
${ }^{36}$ Free to Choose BBC2 debate, March 22, 1980, p. 21 of transcript.

${ }^{37}$ Milton Friedman Speaks, Episode 3, p. 16 of transcript.
}

"Marshall Plan and similar programs" of the U.S. government had "been harmful to the rest of the world" 38 because government-to-government economic aid strengthened the government sector at the expense of the private sector. ${ }^{39}$ It was, nevertheless, as an adviser to the Marshall Plan that Friedman made a second visit to Europe, in late 1950, basing himself in Paris (Friedman, 1992, p. 248; Friedman and Friedman, 1998, Chap. 12).

"Plans to spend a quarter at the London School [of Economics] in the spring of 1952 fell through," Friedman recalled in 1994, "but did lead to my making a three-week trip to Britain and France, giving two lectures at the London School of Economics." 40 Friedman's talk, "Classical CounterRevolution and Monetary Theory and Policy," at the London School of Economics in May 1952, opened with a major gaffe-or a clanger, to use the U.K. nomenclature. His speaking notes state, "With some hesitancy the American speaks on this topic to an English audience. Basic contributions all English. Classical-Hume, Ricardo, Thornton, Marshall..."41 The problem, of course, was that David Hume was Scottish, not English. Indeed, the two British economists with whom Friedman identified most and whom he would most often quote in his writings, Hume and Adam Smith, were Scottish. To judge by Friedman's later statements, he learned his lesson and became more careful about distinguishing the Scottish from the English. In arguing against the Bretton Woods system during Congressional testimony in 1963, Friedman noted that what mattered to the U.K. consumer was a good's U.K. price, not the same price expressed in U.S. dollars; different dollar values of the price were "all the same to an Englishman-or even a Scotsman." 42

Around the time of Friedman's 1952 visit, the U.K. unemployment rate averaged 2.1 percent;

\footnotetext{
${ }^{38}$ September 23, 1971, testimony, in Joint Economic Committee (1971, p. 722).

39 For Friedman's elaborations of this argument, see Friedman (1958a) and Newsweek, December 21, 1970.

${ }^{40}$ From Friedman's notes “1952 MF trip,” in a 1994 letter to Anna Schwartz; courtesy Anna Schwartz.

${ }^{41}$ May 1952 lecture notes by Friedman; courtesy Anna Schwartz.

42 November 14, 1963, testimony, in Joint Economic Committee (1963, p. 454).
} 
in 1951 it was only 1.2 percent, and in 1953 the average was 1.8 percent. ${ }^{43}$ These were lower rates than prevailing in the United States, but Friedman later cautioned against interpreting such low rates as a badge of honor. In his Nobel lecture, Friedman cited the United Kingdom in the 1950s as an example of a country with an inefficiently low unemployment rate, reflecting the fact that a "highly static rigid economy may have a fixed place for everyone” (Friedman, 1977a, p. 459). Friedman elaborated in 2004: "Progress dependsit sounds funny, but it's true-on unemployment... Because that's the only way you can provide the necessary labor force for the new development, the new industries that are coming along"

(Investor's Business Daily, April 15, 2004).

The U.K. economy in the 1950s not only featured an inefficiently low unemployment rate, but also a tendency for aggregate demand to be expanded too rapidly, forcing unemployment temporarily below its low natural value and creating inflationary pressure. Since U.K. policymakers were aware by the late 1940s of the distinction between full and overfull employment, the question arises why they kept overdoing expansion. Some of the overheating in the late 1940s and the 1950s might be attributed to preemptive stimulus in anticipation of a collapse in private demand. Friedman (1973a, p. 5) noted that while "a great post-war depression... was widely predicted," it "kept being expected but it never occurred." This observation was true of the United Kingdom, with Chancellor Dalton stating in 1945 that the "government must arm itself with anti-slump powers, so that never again, as in past years, shall prices, productivity, and employment all fall away through the failure of private enterprise" (Financial Times, November 23, 1945). In particular, "secular stagnation," due to drying up of private investment opportunities and to excessive consumer saving, was feared in the 1940s and cited as a reason for the government stepping in with its own demand for output. Friedman was an early critic of the secular stagnation thesis (Friedman, 1948, p. 262), and the criticism had become widespread by the 1950 s as the prospect of a consumption collapse

${ }^{43}$ London and Cambridge Economic Service (1963, Table F, p. 11). dwindled. In fact, the secular stagnation theory was one aspect of Keynes's thinking that was widely rejected in the United Kingdom even in the Keynesian 1950s; the Financial Times, for example, referred to "Keynes' one-sided fear of over-saving” (May 23, 1955) and to "Keynes' incredibly shortsighted forecast of declining investment opportunities" (October 15, 1956). But precisely because the relevance of the secular stagnation hypothesis was in so much doubt by the 1950s, it is hard to cite belief in it as the reason for continued U.K. overexpansion in that decade.

The repeated failures over the 1950s to deliver the proper dosage of demand seem most attributable to the U.K. government's misguided view of how to affect demand. Here, fiscal policy received pride of place, reflected in Chancellor of the Exchequer Peter Thorneycroft's observation in 1957, "The big instrument of government policy in all these matters is the budget" (Daily Express, July 13, 1957). This contrasts with Friedman's position on fiscal policy which, of course, was this: "In my opinion, a budget deficit is "expansionary' only if it is financed by printing money" (Newsweek, February 15, 1971). According to this interpretation, any apparent connection between fiscal actions and aggregate demand was not an indication of the working of the Keynesian multiplier process, but was instead a by-product (a "disguised reflection" in the terminology of Friedman and Meiselman, 1963) of the fact that deficits in practice were monetized.

Figure 1 plots the ratio of the U.K. budget balance to nominal gross domestic product (GDP), and the growth rate of the U.K. monetary base. The budgetary series is one available for 1948-99, now discontinued but formerly reported as line 80 in hard copies of the International Monetary Fund (IMF)'s International Financial Statistics (IFS). Nominal GDP is the annual average series for the United Kingdom from Haver-IFS (downloaded March 2009). The monetary base series is the annual average of a series obtained by splicing annual averages of the Capie-Webber series (1985) into the Bank of England break-adjusted base money series. The plotted growth rate of the base closely resembles that depicted in Benati (2005, Chart 1), which was based on similar 


\section{Figure 1}

\section{U.K. Budget-Balance Share of GDP versus Monetary Base Growth (1948-99, annual data)}

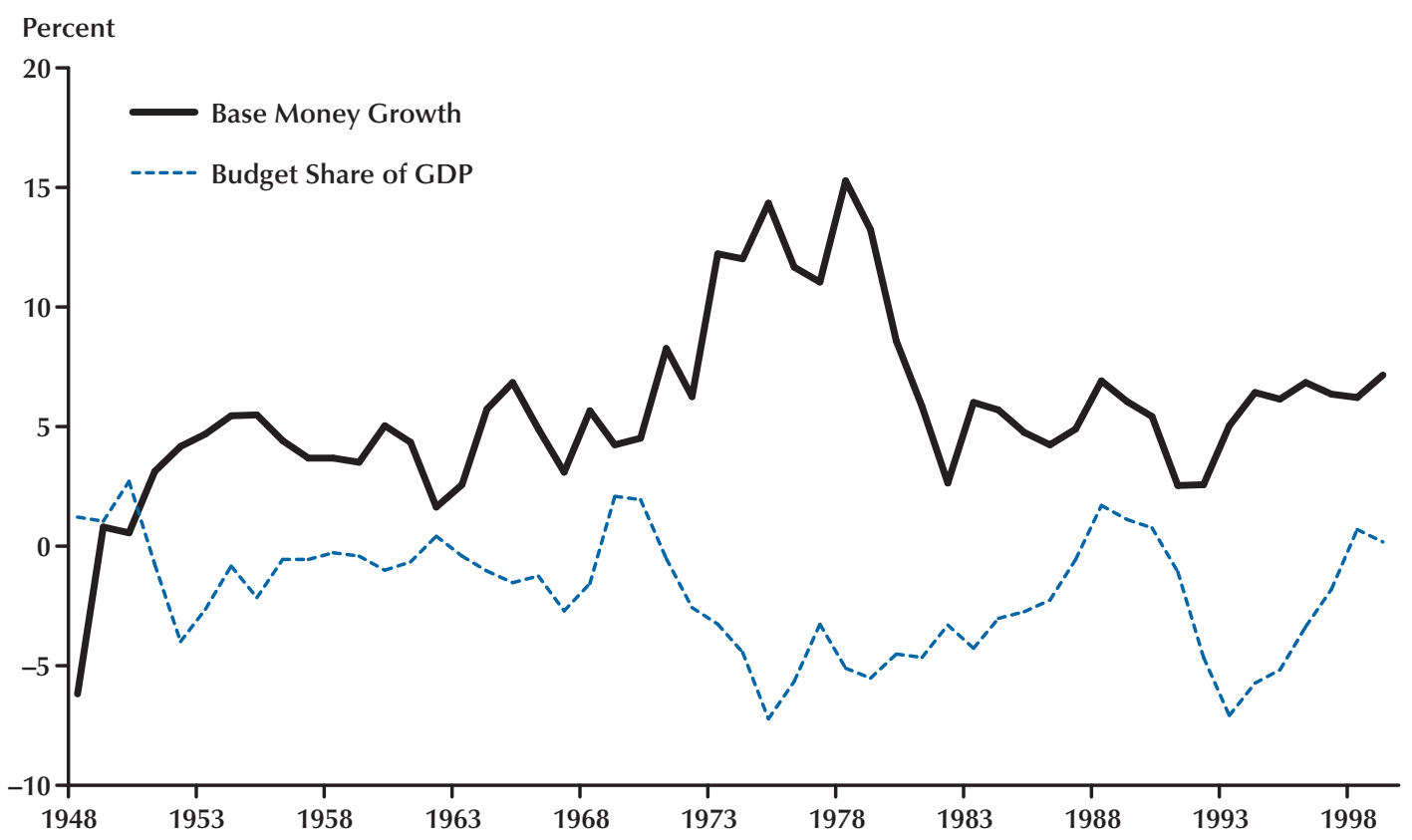

sources; in addition, for 1948-71, the growth rates resemble those of the high-powered money series in Friedman and Schwartz (1982, pp. 125-26). Base growth is highly correlated with the budgetbalance share for 1948-79 (correlation $=-0.80$ ), while the correlation for 1980-99 is negligible (correlation $=0.08$ ). The association between base growth and deficits supports Friedman's contention that in the early postwar decades U.K. government deficits were monetized, ${ }^{44}$ so that the period simply does not provide clean evidence of the effects of "pure" fiscal policy. Attempts to quantify a multiplier impact of deficits and surpluses without attempting to hold constant the reaction of the monetary authorities merely beg the question.

It may seem perplexing that my discussion of demand policies in the United Kingdom in the 1950s has been able to proceed so far without a discussion of the fact that the pound sterling was

${ }^{44}$ Friedman (1975c, pp. 72-73) argues that fiscal deficits were stimulative in Western countries in the postwar period (up to that point) because they were, in practice, monetized. on a fixed exchange rate. I have occasionally seen it argued that the U.K. authorities did not actually pursue Keynesian policies before the 1970s because they were constrained by their Bretton Woods obligations. ${ }^{45}$ This argument overlooks the extent to which foreign exchange controls reduced the impact of the exchange rate constraint on the formation of demand management policy. As Friedman and Schwartz (1963, p. 105) observe in discussing the postwar United Kingdom, "the development of direct exchange and trade controls gave it means of affecting its balance of payments other than through movements in prices and incomes"; relatedly, exchange controls gave the U.K. authorities some room to separate fixing the exchange rate from setting interest rates. There was no occasion in the 1950s when there was a Bank Rate increase that could not be justified by domestic conditions; reflecting this, the Bank of

\footnotetext{
45 This argument was used, for example, by R.J. Ball in the Financial Times, February 4, 1981.
} 
England governor testified in 1958 that foreign exchange market considerations had determined the timing (in terms of the specific week) of Bank Rate moves, but not the actual moves themselves, which were invariably also shaped by internal considerations. ${ }^{46}$ Bretton Woods did not override what the Financial Times (December 21, 1953) called the "modern principle of shaping policy by reference to domestic monetary needs." The coexistence of substantial monetary policy independence and a fixed exchange rate explains why, during the 1950s and 1960s, Lionel Robbins simultaneously criticized the idea of floating rates and advocated that the U.K. monetary authorities manipulate the monetary base to achieve price stability. As Friedman (1978) later pointed out, a bona fide conflict between the exchange rate and domestic considerations in the Bretton Woods system led typically to the exchange rate giving way, as it did in the United Kingdom in 1949, 1967, and 1972.

By the time of Friedman's 1953-54 spell in the United Kingdom, the development of Friedman's monetarism was well advanced, to the point where, in reprinting his (1942) essay on inflation, he added material on money, attributing its previous absence to the "prevailing Keynesian temper" of the 1940s (Friedman, 1953a, p. 253).

Friedman also had had a letter published in The Economist (January 3, 1953) advocating that sterling be floated.

A review of Friedman's Essays in Positive Economics (1953a) appeared in the Financial Times of February 8, 1954, apparently the firstever mention of Friedman in that newspaper. The review was devoted mostly to Friedman's argument for floating exchange rates (Friedman, 1953b). The review said that Friedman "grossly overstates his case... when claiming that flexible exchanges would have obviated the sterling crises of 1947, 1949, and 1951.” The review apparently regarded Friedman as neglecting the possibility that devaluation could worsen the current account balance measured in pounds. This was one of several critiques of Friedman's argument for float-

${ }^{46}$ See the answers by Bank of England Governor Cobbold, in Radcliffe Committee $(1960$, pp. 137, 155). ing exchange rates that took Friedman as implying that a float removes current account deficits in the balance of payments. It is true that Friedman generally regarded depreciations as good for the sterling trade balance and that a low-enough sterling exchange rate would remove the trade deficit; he said so in his 1953 letter to The Economist, for example. But, to my knowledge, Friedman did not claim that a floating exchange rate would converge to the value consistent with a zero trade or current account balance; his claim for floats was the correct and general one that they eliminate the possibility of balance of payments deficits or surpluses, so that "[b]alance of payments problems in the technical sense are a reflection of price fixing." 47

\section{Issues}

The Early Monetarist. Two beliefs are widespread about Friedman's origins as a monetarist. The first belief is that his earliest monetarist work appeared in $1956 .{ }^{48}$ The second is that, in the 1956 paper and elsewhere, Friedman merely dotted the $i$ 's and crossed the t's of existing work by Keynes and of pre-1956 Keynesian work, so that the theoretical innovations of monetarism were negligible (at least if contributions regarding the expectational Phillips curve are put to one side). Both beliefs are misconceptions. They are naturally handled together since the nonKeynesian aspects of Friedman's framework are not all present in his 1956 paper, but are evident if the totality of his work over 1948-58 is considered. The discussion below shows that the literature's characterization of the 1956 paper as the launching pad for Friedman's monetarism has obscured some of the major theoretical differences with Keynesianism that were already visible in other work by Friedman in the 1950s. It complements the cataloguing by Friedman (1972a) and Meltzer (1977) of distinctions between Friedman's framework and Keynesianism but includes items not in their lists. It also serves to

\footnotetext{
${ }^{47}$ September 23, 1971, testimony, in Joint Economic Committee (1971, p. 701).

${ }^{48}$ See, for example, Eshag (1983).
} 
confirm Friedman's observation (in his Reason interview of June 1995) that the key arguments he made in his 1960s' and 1970s' publications were already present in his 1950s' work.

First, Friedman argued as early as 1948 for a focus on monetary policy for the control of inflation. A letter he and other Chicago faculty members wrote to the New York Times in early 1948 was entitled "Control of Prices: Regulation of Money Supply to Halt Inflation Advocated" (January 11, 1948). In claiming that "a marked increase of the general level of prices unaccompanied by a marked increase in the supply of money is a rare if not nonexistent phenomenon," this letter reflected early dissent by Friedman from Keynesianism ${ }^{49}$ and was followed by Friedman's (1950, p. 474) sympathetic remarks about the quantity theory. In 1952, Friedman was firmly associated with the quantity theory position, and Friedman published his finding that income and price changes in U.S. wartime episodes were "more readily explicable by the quantity theory than by the income-expenditure theory" (Friedman, 1952, p. 721$).{ }^{50}$

Second, Friedman (1951) argued for treating prices and wages as endogenous variables at all levels of employment, in contrast to the Keynesian treatment (and Friedman's in 1942-43) of prices as insensitive to aggregate demand until full employment was reached.

Third, Friedman advocated floating exchange rates from 1950, when his (1953b) essay on the subject was drafted, using arguments that rested on the ability of monetary policy to deliver price stability.

Fourth, in the 1950s Friedman rejected costpush factors as a source of sustained inflationary pressure. While Friedman (1948) had given credence to cost-push factors as one factor driving up wages, in 1951 he said, "My views about this have changed considerably in the last few years" (Friedman, 1951, p. 228). In 1952 Friedman testified, "I think the so-called wage-price spiral has

\footnotetext{
${ }^{49}$ Brunner and Meltzer (1993) date Friedman's earliest dissent to Friedman (1944).

${ }^{50}$ Friedman had also confronted Roy Harrod with his views on velocity in a meeting in Chicago in early 1951 (Harrod, 1971, p. 58).
}

been enormously exaggerated, that what we have had has been inflationary pressure pulling both wages and prices up." 51 His rejection of cost-push is clear also in his repudiation in Friedman (1953b) of the idea that exchange rate depreciation could trigger a self-sustaining wage/price spiral. Friedman's position from the early 1950s was that cost-push factors had a zero mean in themselves; upward pressure on wages or prices in one sector would be "balanced by declines elsewhere in other prices and costs." 52 Any tendency for inflation to exhibit a sustained rise in the face of a positive wage or price shock reflected monetary accommodation, so cost-push factors could not alter inflationary expectations in the absence of a monetary expansion. This rejection of cost-push distinguished Friedman not only from Keynesians (among whom the popularity of cost-push explanations increased over the 1950s, in both the United States and the United Kingdom), but also from some advocates of monetary control such as Robbins. In contrast to Friedman, Robbins believed that wage-push factors put a positive bias into U.K. wage inflation, in the face of which monetary policy needed to be contractionary (rather than simply nonaccommodating) to deliver price stability. ${ }^{53}$

Fifth, Friedman rejected the notion of a longrun trade-off between unemployment and inflation. In a 1950 symposium (Wright, 1951, p. 243), Friedman said "I don't know what you mean by saying unemployment will police inflation." In 1952 Congressional testimony he said, "Rather

\footnotetext{
51 March 25, 1952, testimony, in Joint Committee on the Economic Report (1952, p. 727); see also Friedman (1952, fn. 7).

52 March 25, 1952, testimony, in Joint Committee on the Economic Report (1952, p. 736).

${ }^{53}$ Note that the view that unions can be an autonomous source of wage-push is distinct from the view that unions can raise the natural rate of unemployment, since wage- or cost-push refers to inflationary pressure created for a given difference between unemployment and the natural rate. As for whether union pressure could affect the natural rate, Friedman regarded the conditions for this to occur as restrictive- - he argued that unions could raise unemployment in certain sectors, but not necessarily in the aggregate (Friedman, 1951; The Times, August 29, 1973; The Economist, September 28 , 1974)_but he sometimes implied that the conditions for an effect on aggregate unemployment might have been satisfied in the postwar United Kingdom (e.g., Friedman 1963a; Friedman and Friedman, 1980).
} 
than regarding the objectives of high employment and of price stability as inconsistent, I think that fundamentally price stability will promote a high level of output by avoiding a good many of the interruptions to output that we have had in the past, by giving people stable expectations, and so on." 54

Sixth, the preceding two points combined with his doubts about fiscal policy meant that Friedman believed that monetary policy was sufficient to control inflation. The "sufficient" language was used in Friedman (1958b), and contrasts Friedman's position directly with Keynes's view that monetary policy actions could not be sufficient for delivering price stability (see Nelson and Schwartz, 2008).

Turning now to contributions present in Friedman (1956), a seventh 1950s' contribution by Friedman was to specify money demand as dependent on a vector of interest rates. This means that the monetary policy transmission mechanism cannot be summarized by a single interest rate. Patinkin (1969) claims that Friedman's specifying money demand as dependent on interest rates makes his specification Keynesian. This overlooks the fact that Friedman does not condense the nonmoney assets into a single asset, as Keynesian analysis typically did. Moreover, preKeynes writers had made money demand interest elastic, and the specifics of Friedman's money demand approach differ from those of Keynes. Keynes had broken money demand into transactions and speculative components, with only the second component interest-elastic and otherwise “idle." Friedman (1956) rejects the concept of idle money and instead models every unit of money as interest-elastic (possibly relative to own-rates), and held for all motives at the same time (an aspect of Friedman's analysis acknowledged by Patinkin, 1965, p. 75).

Eighth, Friedman (1956) indicates that his conception of money demand rules out the liquid-

\footnotetext{
${ }^{54}$ March 25, 1952, testimony, in Joint Committee on the Economic Report (1952, p. 727). Formulations such as this were precursors to the descriptions of the inflation problem given by many who worked in policymaking from the late 1970s onward, both in the United Kingdom and the United States (regarding the latter, see the statements by Paul Volcker and Alan Greenspan quoted in Lindsey, Orphanides, and Rasche, 2005).
}

ity trap, which he argued in Friedman (1972a) was central to the General Theory. In light of the discussions of the liquidity trap in recent years by Paul Krugman and Lars Svensson, ${ }^{55}$ and their attribution of liquidity-trap views to Keynes, it may come as a surprise that Patinkin (1972a) and many other Keynesians objected to Friedman's association of the General Theory with the liquidity trap. But it was hardly an off-the-wall interpretation on Friedman's part. James Schlesinger, by no means a close ally of Friedman, argued strongly that the liquidity-trap thesis was central to the General Theory in his 20-year retrospective on the book. Schlesinger (1956), Friedman (1972a), and Beenstock (1980) all provide their own, apparently independently constructed, lists of quotations from Keynes (1936) supporting this interpretation, and even Patinkin (1976a) acknowledged that passages of the General Theory treat the liquidity trap as empirically relevant. As Friedman (1972a, p. 942) put it, again and again, Keynes's "final line of defense is absolute liquidity preference."

Over 1948-58, all the elements of Friedman's monetarism fell into place and are recognizable as the positions he took in what he termed the "dispute in the 1950s or early 1960s" in the United States ${ }^{56}$ and in the subsequent debate around the world from the late 1960s. This crystallization of Friedman's framework was occurring when the dominant thinking on monetary policy in the United Kingdom was converging toward an almost completely different framework.

\section{THE ROAD TO RADCLIFFE}

Friedman (1968c, p. 439) noted, "Experience with monetary policy after World War II very quickly produced a renewed interest in money and a renewed belief that money matters." But later, viewing the 1950s and 1960s as a whole, Friedman (1987, p. 13) concluded that the experience of the period "strongly reinforced" the Keynesian critique of monetary policy, and Friedman and Schwartz (1982, p. 17) argue that

\footnotetext{
${ }^{55}$ See, e.g., Krugman (1998) and Svensson (2003).

${ }^{56}$ Friedman (1977b, p. 12).
} 
the revival of the quantity theory of money did not really take off until the 1960s. Evidently, the 1951 abandonment of cheap money policies was not quite as great a breakthrough as Friedman and other advocates of monetary policy had imagined. What went wrong?

Friedman was, on the whole, pleased with the course that monetary policy followed in the United States during the 1950s. But even in the U.S. case he was uneasy about the continuing emphasis on fiscal and other nonmonetary influences when it came to accounting for economic fluctuations; thus Friedman (1955, p. 32) referred to "the intellectual climate of today and the recent past, with its derogation of the significance of monetary factors." Furthermore, diagnoses of inflation were becoming less orthodox with the growing appeal from the mid-1950s of explanations that downplayed demand factors and instead stressed "cost-push."

In the United Kingdom, the trend of opinion against monetary policy was even stronger. The ending of cheap money was more hesitant; certainly interest rates were raised in 1951, but they were cut in 1954 while the economy was gathering steam. The really concerted tightening of monetary policy in the United Kingdom in the 1950s was concentrated in the years 1955-58, which may be why Friedman (1963b, p. 7) once said that the U.K. cheap money period ended "a few years" after 1951. The tightening began with increases in Bank Rate in January-February 1955 under Chancellor of the Exchequer R.A. Butler, and was followed by further increases under his successors in 1956 and 1957. The 1955-58 subperiod distinguishes itself from the preceding and subsequent epochs by the extent to which the authorities were attributed interest in control of the stock of money. For example, Financial Times columnist Harold Wincott contemplated what would happen "if Mr. Butler continues with his policy of contracting the supply of money and credit" (Financial Times, October 4, 1955), while the Financial Times's "Lombard" commentator said that the "ultimate aim of the Government's credit restriction drive is, of course, to exert a downward pressure on the supply of money strong enough to keep spending power within the limits of the country's available resources" (November 30, 1955; emphasis added). In the September 1957 round of tightening, policymakers themselves became very explicit about their intention to restrict the money supply, with speeches to that effect by the prime minister (Harold Macmillan) and Treasury ministers.

The emphasis on monetary aggregates at this early stage may seem anomalous, as the official money series (M0, M1, M3, and so on) that would become familiar in later years were not available. Many have noted that U.K. money supply data were not available to Keynes when he wrote on monetary affairs (see, e.g., Patinkin, 1976b), and Walters (1970) conjectures that a historical series for U.K. money was not put together until the early 1960s. One should not exaggerate the absence of monetary data, however; the weekly release of the Bank of England's balance sheet gave most of the information needed to construct currency and monetary base series; and the various releases of the clearing banks and other institutions provided information on deposits. These releases were the subject of regular attention in the financial press. ${ }^{57}$ The main problem for potential investigators of monetary relations was constructing long series free of breaks and double-counting. It was also well known that the basic data for constructing a long historical money series were available far back for the United Kingdom; Friedman (1961b, p. 270) referred to the availability of U.K. deposit data back to the 1870s.

The would-be revival of monetary policy in the United Kingdom suffered severe criticism once the 1955 interest rate increases failed to deliver the desired results during the year. The Guardian's financial editor had already claimed, "It is now generally agreed that the experiment of checking inflation by monetary policy alone has not been a success" (Manchester Guardian, December 12, 1955).

To many critics, the apparent failure of monetary policy to deliver low inflation vindicated

\footnotetext{
${ }^{57}$ For example, for much of the 1940s and 1950s there was regular space devoted in the Financial Times to the Bank of England's balance sheet release. Deposit data were discussed regularly too; for example, in the Financial Times of November 30, 1955.
} 
the notion that monetary policy was ineffective because aggregate demand was interest inelastic. This notion, already embodied in the General Theory to some extent, ${ }^{58}$ had been reinforced in the United Kingdom in the prewar and early postwar period by surveys of firms carried out by Oxford University. The survey results seemed, as discussed, for example, by Schlesinger (1956, p. 603), to vindicate the view that firms' investment decisions were interest inelastic (and with them the whole of aggregate demand, as most Keynesian work had already narrowed the interest rate channel to investment).

Friedman was scathing about the value of questionnaires of businessmen. "That is not evidence...I do not care what they have said," he said on a panel in $1950 .{ }^{59}$ In 1979, Friedman added, "Economics is a serious subject, and one of the things we've learned in that subject is that if you want to know how people behave, you don't ask them. You look."60 The joint behavior of real returns and the stock of productive capital led Friedman to believe that investment was instead "highly elastic" with respect to real interest rates (Friedman and Schwartz, 1982, p. 494). Friedman's reaction to the survey results paralleled that of his hero Dennis Robertson, who had said in 1949 that he had "a hunch that the reaction among the neo-Keynesians against the importance of the causal influence of the rate of interest on capital outlay has been carried too far...Does anyone here, I wonder, share my doubts-my very respectful doubts-about the significance of those replies to questionnaires?” (Robertson, 1949, p. 20).

Keynesians not only doubted the effectiveness of monetary policy as a demand-control measure; they argued that efforts to control inflation via demand measures might in any case be misguided. The Financial Times editorialized during the initial tightenings that there was "still something of a mystery about the origins of the inflationary forces threatening the British economy" (February 15, 1955). Despite their use of monetary

\footnotetext{
${ }^{58}$ See, for example, the passage cited in Patinkin (1976a, p. 103).

${ }^{59}$ Friedman, speaking in Wright (1951, p. 251).

${ }^{60}$ In Anderson (1982, pp. 201-02).
}

policy tightening, policymakers shared the view that much inflation was cost-push in character, a view evident in their repeated attempts to secure an agreement with the private sector on wage growth limits.

The skeptical sentiments regarding monetary policy made by Keynesians since the 1930s were synthesized and consolidated in the report on monetary policy delivered by the Radcliffe Committee to the U.K. government in August 1959. The Radcliffe Report argued that monetary policy was ineffective. It did not rely on the liquidity trap argument but used lines of reasoning that delivered as complete an ineffectiveness result as that associated with the liquidity trap. Whereas Keynes's liquidity trap argument said that money and government securities could become equivalent at a low interest rate, the Radcliffe Committee argued that important asset prices were unaffected by open market operations that switched money for short-term securities, even when these operations changed the short-term interest rate. Thus while open market operations could alter policy rates, they affected only the composition, not the aggregate, of "liquidity," which was the financial quantity that really mattered; financial innovation, it was argued, had eliminated much of the difference between money and Treasury bills. The interest rates that policy could affect, the Committee argued, mattered negligibly for aggregate demand, while the asset prices that did matter for aggregate demand depended on the "liquidity" total, which was generally not susceptible to central bank manipulation. The Committee also endorsed cost-push views of inflation. ${ }^{61}$

Friedman and Schwartz (1982, p. 52) observe that the Radcliffe Committee was "faithful to Keynes" in emphasizing the ineffectiveness of monetary policy arising from the alleged equivalence of money and securities. But the Committee, by claiming that monetary policy was ineffective generally, not just in Depression conditions, was taking a harder-line position than Keynes usually did. The Committee's basis for this conclusion

\footnotetext{
${ }^{61}$ See Radcliffe Committee (1959); and for references to the relevant sections, see, e.g., Laidler (1989) and Nelson (2009).
} 
was that financial innovation-for example, the growth of nonbank intermediaries-put the determination of important asset prices outside the reach of monetary policy. While the emphasis on financial innovation did not have a counterpart in Keynes's General Theory, it paralleled the approach that Gurley and Shaw (1960) were taking in analyzing U.S. financial behavior. Noting the connection, Friedman and Schwartz (1970) treated Gurley-Shaw and Radcliffe as advocates of the same "liquidity" argument, while Friedman and Schwartz (1982, p. 209) referenced Radcliffe and Gurley-Shaw together when citing studies that minimized the significance of money and monetary policy actions. Monetarists were not impressed by the Radcliffe/Gurley-Shaw arguments from the beginning, and the monetarist side of the argument was what-eventuallywon the day in the economics profession. Brunner (1985, p. 22) observed witheringly that there really was "no logical link between negative conclusions bearing on monetary policy, and the discussion of financial innovations...Gurley and Shaw argued more than 20 years ago that the explosive growth of savings and loans associations erodes the potency of monetary policy. The subsequent evolution discredited such fears or hopes."

Friedman's initial public response to the Radcliffe Report was muted. Alvin Marty thanked Friedman for "exceedingly helpful substantive comments" on a paper published in early 1961 in which Marty said the "Radcliffe Report is a striking example of failure to offer a shred of evidence."62 In a book review published at the end of 1961, Friedman (1961a, pp. 1052-53) noted the problems in defining "liquidity"; in 1964, he said that the Radcliffe Committee's liquidity concept was "an undefined term which covers the universe,"63 while Friedman and Schwartz (1970, p. 130) added that the Radcliffe Committee itself could not settle on a firm liquidity definition. ${ }^{64}$ Friedman denounced the theories offered by the Radcliffe

\footnotetext{
${ }^{62}$ Marty (1961, pp. 56, 59).

${ }^{63}$ Friedman (1964a; p. 73 of 1969 reprint).

${ }^{64}$ The critical discussion of the Radcliffe Committee in Friedman and Schwartz (1970) was originally part of their unpublished first draft of their Trends study (Friedman and Schwartz, 1966).
}

Committee as "a false trail that will not in fact be productive" (Friedman, 1963b, p. 9) and went on to applaud the negative reception the Radcliffe Report had received among "academic economists and others." 65 Friedman's appraisal that the Report had been received negatively rested largely on the U.S. reaction; in the United Kingdom, many policy and academic figures greeted the Report favorably.

In U.K. policymaking, confidence in monetary policy restriction as the cure for inflation reached its peak in 1957 and was followed by a period of substantial monetary policy easing. Friedman (1980b) argued that the shift to expansionary policies (both monetary and fiscal) in the United Kingdom from the later 1950s onward was a vindication of his (1954) prediction. He had predicted that overreaction to actual or prospective minor recessions would produce a tendency for the authorities to overexpand. Complementing this explanation is the fact that the U.K. authorities after 1957 were much more inclined to view incomes policies as the appropriate means of fighting inflation. Even when inflation fell in the late 1950s, to the point of delivering price stability in 1960, the success was attributed to favorable cost-push shocks rather than to the 1955-58 restrictive monetary policy. For example, The Economist (August 29, 1970) attributed the fall in inflation from 1958 to 1960 to less-militant union behavior after the defeat of the 1958 London bus strike.

\section{9-1970}

\section{Events}

In a new round of monetary policy tightening in July 1961, the Macmillan government raised Bank Rate to 7 percent. This was not an unambiguous affirmation of the role on monetary policy, because it was muddied by a simultaneous attempt by the government at a wage freeze (a "pay pause"). But after a year of tight monetary policy, the Chancellor of the Exchequer, Selwyn Lloyd, showed signs of determination to maintain

\footnotetext{
${ }^{65}$ Friedman (1964a; p. 73 of 1969 reprint).
} 
Figure 2

\section{U.K. M2 and Monetary Base Growth (1948-75, annual data)}

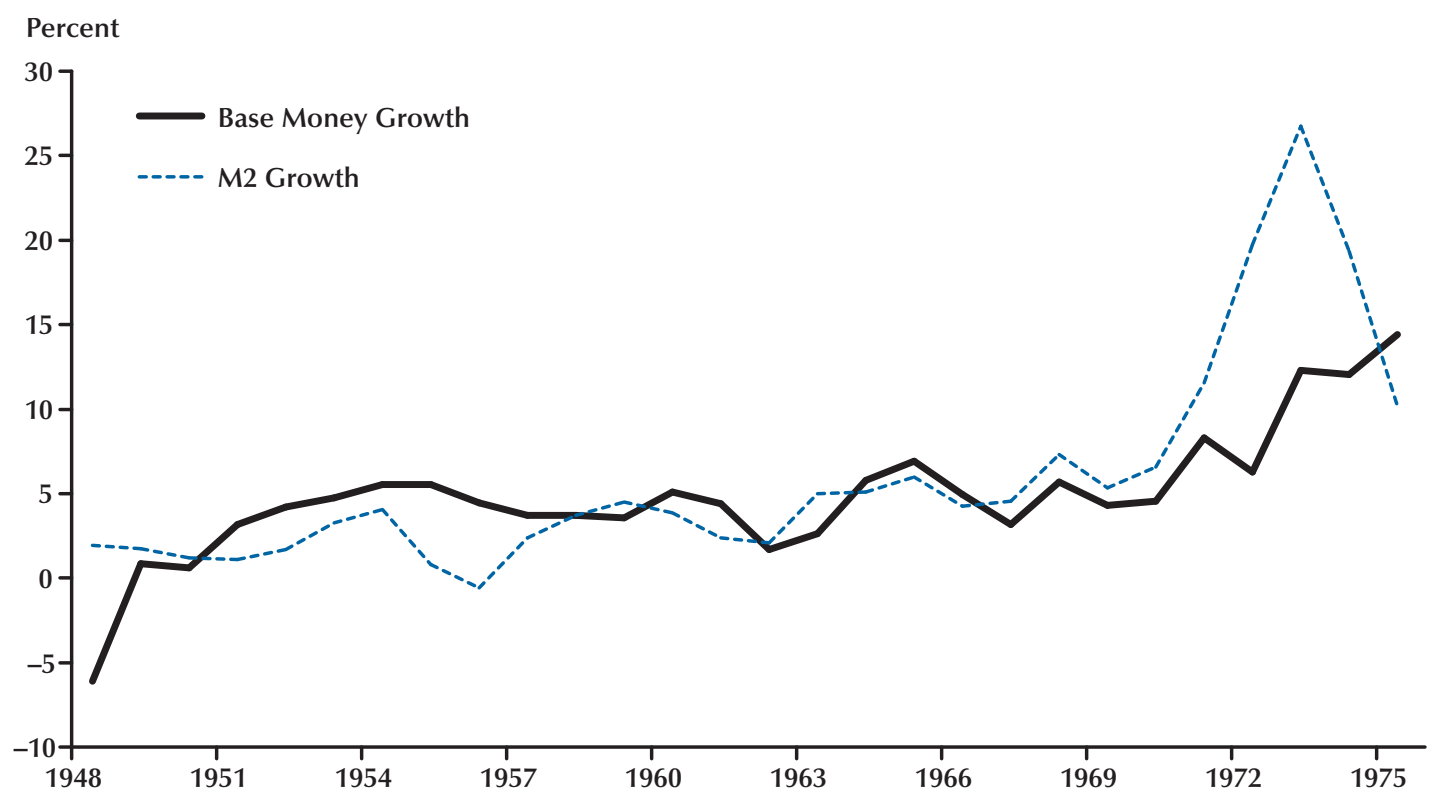

a restrictive stance: "18 months ago there was excess demand...Now, I think there is a measure of disinflation...I think the economy is in better shape, but you can't have disinflationary measures without there being, in result, a measure of disinflation...That means that some order books will be shorter" (Yorkshire Post, July 11, 1962). Shortly afterward, Lloyd was fired. The restrictive monetary policy episode turned out to be only an interruption in the de-emphasis on monetary policy signaled by the Radcliffe Report. The expansionary policies prevailing before 1961 were revived in a more-intense form. The more-expansionary policy was associated with a shift up in money growth, whether measured by the monetary base or by Friedman and Schwartz's (1982) M2 measure, reversing the moderation in growth observed during the 1961 squeeze (Figure 2). Consequently, while the pickup in U.S. money growth in the 1960s initially exceeded that in the United Kingdom, Friedman and Schwartz (1982, p. 157) note that, from the mid-1960s, "the United Kingdom took the lead-if that is the right word."
Friedman viewed the U.K. monetary expansion of the 1960s as contributing to the mood of the country. "[T] he fact is that most people enjoy the early stages of the inflationary process. Take, for example, Britain in the Swinging Sixties" (The Listener, April 24, 1980). One aspect of the sustained expansionary policies of the 1960s that did cause concern to the U.K. authorities was one that Friedman would prefer they had been sanguine about: the threat to the exchange rate. The sterling/dollar rate was becoming more difficult to maintain, even with the exchange control apparatus, and speculation against it increased after the Labour Party under Harold Wilson was elected to office in 1964. Friedman (1965, p. 179) said that while he happened to disagree with the policies Wilson had promised to carry out, he found it objectionable that foreign central banks and other holders of sterling were perceived as having a "veto power" over their implementation. He elaborated in September 1965 that this meant "that British internal policy was shaped by officials who were not responsible to the British 
electorate."66 Friedman concluded that Wilson, instead of negotiating a sterling rescue, should have floated the pound on coming to office, blaming the predecessor government for the likely depreciation. ${ }^{67}$

The Wilson government finally did devalue the pound sterling in November 1967, with the 14 percent adjustment providing another example of what Friedman (1969, p. 20) called "this awful business of holding and holding and holding to the last gasp and then having to make a big change." Friedman had anticipated the devaluation and had wanted to speculate $\$ 30,000$ against the pound, only to find that his Chicago banks did not have the wherewithal to carry out the foreign exchange transaction (Sydney Morning Herald, October 9, 1986). After the devaluation, the Wilson government started expressing policy commitments to the IMF in terms of quantitative financial targets, and in 1969 it announced a target for domestic credit expansion (DCE). Although interpreted as a concession to monetarists, the DCE targets had the decidedly un-monetarist implication of encouraging the authorities to regard money base growth that came from balance of payments surpluses as "good." The policy framework of a fixed exchange rate, attention to DCE at the expense of the aggregate monetary base, and incomes policies, contrasted with Friedman's recommendation of a sterling float, no incomes policy, and direct control of the aggregate base or aggregate bank reserves.

\section{Issues}

Monetarism and the Quantity Theory. It is difficult to convey the dramatic shift in the amount of coverage given to monetary policy in the U.K. financial press and political debate in the years 1968 to 1970 compared with the preceding three years 1965 to 1967 . The increased degree of coverage turned out to be permanent. Some flavor is captured by the observation of the magazine Management Today (August 1976):

\footnotetext{
66 From Friedman's 1965 Mont Pelerin Society meeting remarks, published in Friedman (1968a, p. 274).

67 See, e.g., his remarks in Friedman and Roosa (1967, pp. 114-15)
} and his 1968 memorandum in Friedman (1988).
"A decade ago economists, pundits and politicians alike would have been amazed to learn that in the mid-1970s debates over monetary policy would have come to dominate the national and international economic scene."

The upsurge in the coverage of monetary policy was accompanied by greatly increased discussion of Friedman. While "Chicago School" was probably the most widely used term to describe the school of thought emphasizing money (e.g., The Sun, October 7, 1968; The Observer, April 20, 1969), and "Friedmanite" was used from an early stage (e.g., Sunday Times, November 10, 1968), the U.K. debate also rapidly proliferated a term that The Economist had used as early as 1963, but which was starting to become prevalent in the United States: "monetarist." Robert Solow used "monetarism" repeatedly in an article he wrote for The Times (December 23, 1968), and Paul Samuelson criticized "crude monetarism" in a contribution to the Sunday Telegraph (December 15, 1968).

Friedman often publicly criticized the terms "monetarist" or "monetarism." In an interview with The Times in 1976, Friedman said, "It is not a new position, and that is one of the reasons I don't like the word monetarism" (The Times, September 13, 1976). ${ }^{68}$ As Friedman saw it, he was not launching a new theory but bringing quantity theorists' work "down to date," 69 so that it could be applied to the problems of the "bad old present."70 But Friedman (1978) confessed that there was utility to the term monetarism because there were some elements of older quantity theory work that he and other monetarists had discarded. In particular, an aspect of earlier quantity theory analysis that Friedman explicitly rejected was regarding velocity behavior as the outcome of an institutionally determined payments process,

\footnotetext{
${ }^{68}$ Anna Schwartz has suggested that another reason for Friedman's reservations about the word "monetarism" is that "I think he attributed it to Karl Brunner, who was not really a master of English." (Conversation with author, trip to Vermont Great Inflation conference, September 25, 2008.) Brunner is typically credited with the term monetarist or monetarism, but both terms predate Brunner's usage of them (see Laidler, 2001; and the Oxford English Dictionary, 1976 and online editions).

${ }^{69}$ Friedman (1972d, p. 12).

${ }^{70}$ Friedman speaking in The Guardian, September 16, 1974.
} 
instead of as the result of decision problems by households (e.g., Friedman, 1956, point 11; Friedman, 1963b, p. 10; Friedman and Schwartz, 1982, pp. 38, 40, 62). Friedman himself used "monetarism" and "monetarist" in his address at the University of London (1970a). He became accustomed to using these terms readily and without prompting, including in correspondence and conversation.

On some occasions Friedman also associated the older quantity theory with a further retrograde aspect, namely the assumption of price flexibility, or, more fairly, of not having a firm description of the adjustment process of prices to money (e.g., Friedman and Schwartz, 1982, p. 44). But he generally qualified this case by describing it as the "simple quantity theory" (e.g., Friedman and Schwartz, 1982, pp. 59, 398). Further consideration by Friedman during the 1970s of the quantitytheory literature had the effect of leading him, if anything, to attribute more to the older writers. In particular, Friedman was struck by how explicit David Hume's writings had been on the role of expectations: "David Hume has a statement somewhere about the fact that an increase in the quantity of money stimulates economic activity only so long as it keeps on increasing and people don't expect it" (The Times, September 13, 1976).

Friedman decided that while he, and Lucas and Sargent after him, had expressed the point more formally, the expectational Phillips curve idea was due to Hume (Friedman, 1975b). While Patinkin (1972b) claimed that Hume did not believe in a long-run vertical Phillips curve, the explicit quotations given in Friedman (1975b) support the crediting of this idea to Hume, and Friedman's interpretation was more recently reaffirmed by Mankiw (2001) in his study of the same Hume passages.

Friedman further credited Hume with the demand-for-money perspective on the quantity theory that Friedman had used (Friedman and Schwartz, 1982, p. 621). So whereas Friedman (1968c, p. 433) attributed to Hume the "broad outlines of the quantity theory," by the early 1980s he was crediting Hume with both the aggregate demand and aggregate supply aspects of his own framework and so, he said, Hume was the true originator of monetarism. Appropriately enough, it was on British television that Friedman said: "I really would like to make clear that the doctrines I proclaim are not original with me by any means, in fact if I have to find a source for them they are [from] David Hume."71

In their interventions in the U.K. debate, Samuelson and Solow argued that monetarism was not making valid points about monetary relations that U.S. Keynesianism had not long since incorporated. Samuelson, for example, said: "Money was, so to speak, 'rediscovered' in my country around 1950...When Professor Friedman formulates his system in generality...it coincides with the post-Keynesianism of the TobinModigliani type.” But the record does not support the denial of Friedman's contributions, nor Samuelson and Solow's confidence that U.S. Keynesianism circa 1968 had incorporated the role for monetary policy adequately. As we have seen, Friedman's emphasis on money predated 1950, and his elaboration of it incorporated a general transmission mechanism not covered in Keynesian work; in particular, more than one interest rate, and (in contrast to positions taken by Samuelson and Modigliani) a sensitivity of consumption (not merely investment) to interest rates. ${ }^{72}$ Furthermore, Solow and Samuelson in both the 1960s and 1970s disputed Friedman's expectational Phillips curve analysis, contesting both its long-run vertical property and its exclusion of a systematic role for cost-push factors. In well-known lectures given in Manchester, for example, Solow (1969) argued that cost-push factors mattered greatly in both the United Kingdom and the United States, that demand factors barely mattered at all for U.K. inflation, and that the U.S. Phillips curve was permanently nonvertical.

Some influence of the money supply debate was felt in what policymakers said: Chancellor

\footnotetext{
${ }^{71}$ Free to Choose, BBC2 debate, March 22, 1980, p. 15 of transcript. Likewise, at a press conference in Wellington, New Zealand, in 1981, Friedman said, "What is called monetarism, the quantity theory of money, was developed by David Hume in the eighteenth century. It is not 'my' theory-I have no patent on it" (Evening Post, April 27, 1981).

${ }^{72}$ See Blinder (1986) and Modigliani (1986) for characterizations of the pre-monetarist Keynesian view as one that denied the interest sensitivity of consumption.
} 
of the Exchequer Roy Jenkins stated, "I attach the greatest importance to monetary policy" (House of Commons Debates, April 15, 1969, p. 1007); and The Economist (April 18, 1970) referred to the "new importance attached to monetary policy in Britain." As noted above, however, the changes actually made in the macroeconomic policy framework were not truly in the direction Friedman wanted. Indeed, at the U.K. Treasury, skepticism prevailed from top to bottom about the attention being given to Friedman. At a junior level, Treasury economist Stephanie Edge spoke in favor of the power of fiscal policy and criticized Friedman's findings to the contrary: "The idea that simple one-equation comparisons can reveal anything is one that should be vigorously attacked" (Edge, 1967, p. 205). At a senior level, Treasury adviser Alec Cairncross wrote in his diary of October 6, 1968, that "the English press (and especially The Times) was making such a fool of itself over Milton Friedman” (Cairncross, 1997, p. 327).

Cairncross's reference to The Times concerned the articles being written by its economics editor, Peter Jay. Jay was initially regarded with suspicion on each side of the money supply debate as a sympathizer with the other side. But further articles by Jay brought him out as a supporter of the monetarist arguments, and Jay later identified himself among "those... who began to advocate proper control of the money supply from the late 1960s" (Independent, September 23, 1991). Friedman and Jay became good friends, appearing together on several episodes of both the U.S. and U.K. versions of the Free to Choose television program in 1980. In one of these programs, Friedman said that he and Jay "are in almost complete agreement on the desirable monetary policy."73

Another journalist, Samuel Brittan, serves as an illustration of Friedman's observation that "accidents play an enormous role in mankind's experience."74 Friedman happened to be visiting Cambridge University while Brittan was an undergraduate student there, and Brittan happened to

\footnotetext{
${ }^{73}$ Free to Choose, PBS debate, Episode 3, pp. 16-17 of PDF transcript.

${ }^{74}$ April 16, 1996, talk by Friedman at Claremont College (broadcast C-SPAN, December 26, 1996).
}

have Friedman assigned to him as his tutor. Brittan joined the Financial Times after graduation. Brittan considered the arrival of monetarism the "most interesting event for a very long time in the realm of economic ideas" (Financial Times, January 8, 1970). A long article by Brittan, headed "MONEY SUPPLY: The Great Debate" in an enormous font, appeared in the October 25, 1968, edition of the Financial Times, discussing Friedman's views and covering his American Economic Association presidential address (Friedman, 1968b). Brittan and David Laidler, who had been a Ph.D. student of Friedman's at Chicago and from the late 1960s was at Manchester University, became two leading voices of monetarism in the United Kingdom during the 1970s. Cobham (1984) notes that although Laidler departed for Canada in 1975, he remained prominent in the U.K. debate during the second half of the 1970s. Neither Brittan nor Laidler was an echo chamber for Friedman, and both disagreed with him in print, but they both had firsthand knowledge of his positions. As Friedman observed, "You have the interesting phenomenon that whereas David Laidler came to Chicago, Chicago came to Sam Brittan."75

Alan Walters, an academic and financial consultant who had been undertaking U.K. analogues of some of Friedman's empirical work since the early 1960s, wrote to Friedman at the end of the decade to let him know that he was close to being a household name in the United Kingdom. ${ }^{76}$

The Beginning of Monetary Trends. In November 1966, Friedman and Anna Schwartz completed a draft of their manuscript on monetary trends, concerned solely with U.S. data, and submitted it to the NBER review process. Friedman (1955, p. 30) had written about the desirability of studying U.K. monetary data, and, somewhere along the line, Friedman and Schwartz elected to cover U.K. data in the revised version of their Trends manuscript, although it was not a change specifically requested by the NBER. A major obstacle, the construction of historical data, was

\footnotetext{
${ }^{75}$ Friedman, speaking in September 1974, in Institute of Economic Affairs (1974, p. 102).

${ }^{76}$ Letter from Alan Walters to Milton Friedman, December 4, 1969, Friedman office correspondence (uncatalogued as of end-2007).
} 
partly overcome when David Sheppard, a Harvard Ph.D. graduate shortly to return to the United Kingdom, contacted Friedman to let him know of his work in the area. In his reply to Sheppard, Friedman indicated that U.K. data were being incorporated into his new volume with Schwartz. ${ }^{77} \mathrm{He}$ and Schwartz thereafter used the Sheppard data on money. Anna Schwartz used the data in a 1969 paper for U.K. audiences (Schwartz, 1969), and Friedman referred fleetingly to the Trends project during Congressional testimony in October 1969, where he said he had been "working on some British data which go back a century. They show the same relation [as in the United States]." ${ }^{78}$ Considering this energetic start in the late 1960s, Friedman and Schwartz surely could not have imagined that Monetary Trends would not be finished until the early 1980s.

\section{0-1979}

\section{Events}

The Conservative Party, led by Edward Heath, won the U.K. general election of June 1970. Friedman had not met Heath (The Listener, February 11, 1971). There is nevertheless evidence of an influence of Friedman's writings on Heath's statements. Heath's introduction to his 1970 party platform said, "[O]nce a policy is established, the Prime Minister and his colleagues should have the courage to stick to it. Nothing has done Britain more harm in the world than the endless backing and filling which we have seen in recent years" (The Guardian, May 27, 1970). It is possible that the drafting of this passage was influenced by Friedman and Schwartz's (1963, p. 289) characterization of the Federal Reserve's history as one of "so much backing and filling, so much confusion about purpose..."

There was less indication that the new government would be influenced by the Friedman-

\footnotetext{
${ }^{77}$ Friedman, letter to David K. Sheppard, July 10, 1967, Friedman office files (uncatalogued as of end-2007).

${ }^{78}$ October 6, 1969, testimony, in Joint Economic Committee (1970, p. 826).
}

Schwartz work when it came to monetary policy formulation, as Anna Schwartz discovered on a visit to the United Kingdom very soon after the election result. Writing to Friedman about her meetings with U.K. academic economists and Bank of England officials, Schwartz reported: "Much talk generally of what difference the Conservative Government would make for monetary policy...[The Bank officials] didn't see that it would make any difference. Apparently, Bank policy is perfect."79

On the matter of the government's role in the market, the prospect seemed more favorable that U.K. economic policy would go in a direction favored by Friedman. Friedman said in 1971, "My own personal view is that...the most effective road to development is through free enterprise and private investment, and that the government can serve best by limiting itself to essential government functions." 80 In the same year, the Heath government objectives were laid out by the Chancellor of the Exchequer, Tony Barber, in a form that seemed in keeping with Friedman's views: "Our object is to lessen government interference and reduce government subsidies; to extend the opportunities for profitable enterprise; to widen the area within which industry rather than government will make decisions" (Dallas Morning News, February 9, 1971). Friedman expressed cautious approval, observing that the United Kingdom had "potential, but only if you could by some miracle get rid of the enormous mass of controls, interventions, welfare-state measures and so on...Heath has been moving somewhat in that direction" (Vision, April 1972).

The Heath government moved away from free-market policies during 1971 and made the break more explicit with the passage of the Industry Act 1972. The act introduced extensive subsidies to private investment, contrary to Friedman's dictum, "Capital investment that has to be subsidized is not worth having" (Wall Street Journal, February 12, 1997).

\footnotetext{
${ }^{79}$ July 2, 1970, letter from Anna Schwartz to Friedman. The Hoover Archives' copy of this letter is in Box 91, folder 7, of the Friedman papers.

${ }^{80}$ Friedman (1971a, p. 847).
} 
The change in direction was felt also in the Heath government's policies against inflation. The government started cutting Bank Rate in April 1971. It had consistently seen inflation as a nonmonetary problem and in November 1972 imposed wage-price controls.

Also in 1970, Friedman had his first published exchange with a U.K. critic of his work. The Radcliffe Report had given Friedman a heads-up about the skepticism regarding monetary policy prevailing in the United Kingdom. Along with Richard Kahn, Nicholas Kaldor was regarded as a major academic influence on the Report. Shortly before Friedman's visit, Kaldor (1970) restated the U.K. anti-monetary policy position and used a reverse causation argument to dispute Friedman's findings. If, Kaldor argued, the authorities actually undertook measures that delivered them control of the money stock, their actions on money would face permanent, completely offsetting movements in velocity. Historical relations between money and other variables, according to this argument, simply reflected reverse causation-the passive creation of money in response to price and output movements. Price and output behavior would, it was argued, have been no different if the monetary authorities had somehow prevented this money creation from taking place.

The way that Friedman (1970c) answered Kaldor was by appealing to the fact that money had been connected to income and inflation under many different monetary arrangements, undermining an explanation of the correlation like Kaldor's that relied on the existence of a particular policy regime or on the institutional conditions prevailing in the United Kingdom.

The Bretton Woods system collapsed during the early 1970s, despite what Friedman said was officials' belief that "they can put Humpty Dumpty together again." 81 The London Evening Standard's financial columnist blamed the foreign exchange market turmoil on the "incredible influence of economist Milton Friedman," charging that Friedman's theories had discouraged international coordination of policies (May 5, 1971). Though

${ }^{81}$ September 23, 1971, testimony, in Joint Economic Committee (1971, p. 699). he would surely have liked to accept the credit for the advent of floating rates, Friedman concluded that his advocacy of flexible rates had had "absolutely no effect," and that it was instead the "brute force of events" that had forced governments to realize that fixed exchange rates were untenable (The Listener, April 27, 1978). The pound sterling began floating in June 1972.

In early December 1972, Friedman learned that a debate had been taking place in the London Times about his 1967 American Economic Association presidential address. His statement there (Friedman, 1968b, p. 11), that "full adjustment" to a shift in the inflation rate takes "a couple of decades," had been interpreted by one critic as implying that removing inflation would take 20 years of above-normal unemployment. Friedman wrote a letter to The Times (dated December 6 and published December 12) to clarify that by "full adjustment" he meant resettling at the steady state. "The important point is that while 'full' adjustment may well last several decades, the period of unusually high unemployment is far shorter, more like two to five years." Around the same time, in a submission to the U.S. Congress Joint Economic Committee, Friedman had occasion to convey his opinion of the U.K./France Concorde project. That project had reached fruition partly from the injection of funds from the U.K. government. The result was an air service that took hours off of intercontinental travel, but only for the elite class of customers who could afford the ultrahigh ticket prices. Friedman (1958a) had criticized the involvement of the government sector in the creation of "monuments" that did not raise ordinary living standards, and his Congressional submission (dated December 11, 1972) urged that the United States government not follow the Concorde precedent by subsidizing a U.S. supersonic transport (SST). "A governmental decision to produce an SST largely at its own expense is a step toward socialism and away from free enterprise." 82

Though the preceding two items do not appear in his published bibliographies, they could easily have become the last things Friedman ever wrote

\footnotetext{
${ }^{82}$ In Joint Economic Committee (1973a, p. 81).
} 
for publication. On December 15, Friedman had open-heart surgery. The surgery was successful and Friedman was discharged on December 26 (Kansas City Times, December 27, 1972), but Friedman lost considerable weight in the wake of the surgery, and his family medical history was inauspicious. As Anna Schwartz has observed, "Who would have thought at that time that Friedman would live on to ninety-four?"83

From the United States, Friedman criticized U.K. monetary policy developments during 1973, observing in Congressional testimony that "defective as our policy has been, it has been less erratic, more moderate than the policy of most other leading countries." $84 \mathrm{He}$ observed later in the year that Heath had gone from what Friedman perhaps too generously called a "tight money policy" to "a policy of stimulating... Now you have prices rising in Britain at a rate of something over $10 \%$ a year" (Friedman, 1973b, p. 33). The British magazine Management Today pondered Heath's and Friedman's contrasting diagnoses of the inflation problem in its August 1973 issue: "But is the entire phenomenon of unusually rapid and apparently ineradicable inflation new in itself?," its editorial asked. "Is it a different variety, considerably more virulent, of the disease to which Western society has been susceptible for many decades past? The temptation, of course, is to say that it is: to blame union militancy...But economic historians half a century hence may well not be impressed by this argument. To them, the inflation will probably seem a classic case of monetary inflation, engendered by the usual process of overproduction of liquid currencies."

The editorial just quoted was something of an outlier in the general U.K. discussion in 1973. The tendency to consider inflation to be nonmonetary in character intensified in the wake of the oil and other commodity price shocks of that year. Wherever he went during the 1970s, Friedman found himself having to explain the fallacy inherent in special-factor explanations

\footnotetext{
${ }^{83}$ Remarks of Anna Schwartz to author, New York office of NBER, May 27, 2008.

${ }^{84}$ Friedman, June 21, 1973, testimony, in Joint Economic Committee (1973b, p. 120).
}

for inflation. "Arithmetic is one thing and economics is a very different thing," was how Friedman put it in one appearance (Meet the Press, November 12, 1978). "The great confusion in this area is to confuse particular prices with prices in general.” In 1979 Friedman, perhaps near his wit's end, reiterated: "OPEC does not cause inflation; no, sir." 85

What Friedman (1975a, p. 137) called the U.K.'s “major economic crisis in early 1974," with U.K. inflation passing 15 percent, culminated in an election that returned Harold Wilson to power. Friedman noted that the recent U.K. elections had helped refute the claim that governments do not lose elections because of high inflation. "Inflation surely helped to make Mr. Edward Heath Prime Minister in 1970," Friedman (1974, p. 44) observed, "and, even more surely, ex-Prime Minister in 1974."

The centerpiece of the Wilson government's incomes policies measures was intended to be its "Social Contract" agreement with the unions. Friedman said that "the so-called Social Contract... gives people a false impression of both the causes of inflation and the way to cure it" (BBC2,

November 9, 1976). The Social Contract would do "no good whatsoever as long as they continue to run the printing press" (Friedman, 1975d, p. 20); and, if money growth was slowed, the Social Contract would be seen as having been successful, even though the reduction in inflation would be the same without the Contract (Newsweek, September 20, 1976).

Friedman paid a one-week visit to the United Kingdom in September 1974. Reflecting on his visit a few months later, Friedman was particularly struck by the continuing popularity of the wage-push explanation. "In Britain, the explanation that everybody gives for inflation is that inflation is caused by trade unions, the greedy grasping laborers who force up the wages that cause inflation" (Friedman, 1975d, pp. 5, 7). During his visit Friedman had written to The Economist saying he had "been dismayed, even in my few days in London, at the widespread

\footnotetext{
${ }^{85}$ May 17, 1979, testimony, in Committee on the Judiciary (1980, p. 154.)
} 
support of 'union bashing' as a way to attack inflation” (The Economist, September 28, 1974).

While Friedman argued in 1978 that there was "almost no one who any longer has a good word to say about nationalization," he had to admit that in the United Kingdom the trend had been to extension of nationalization (The Listener, April 27, 1978). Indeed, Harold Wilson's account of his 1974-76 term in office (Wilson, 1979, p. 35) includes a six-line list of the nationalization plans his government outlined in 1974, and the Labour government did proceed to extend nationalization to the shipbuilding industry. With Thomas Balogh, one of Friedman's Keynesian opponents, as one of the ministers responsible, the Department of Energy also increased the government's stake in the oil industry-leading to Friedman's observation, "You have been nationalizing North Sea oil" (The Listener, April 27, 1978). Some of the oil-industry nationalization was wound back in the austerity measures of late 1976, when the Callaghan government announced the sale of part of its interest in British Petroleum.

The U.K. private corporate sector over this period was suffering a pronounced squeeze. "Great Britain had a much more severe financial crisis than we did," Friedman observed. ${ }^{86}$ The stock market experienced a major collapse, its index standing in 1974 at its late 1950s' value (Bordo and Wheelock, 2004), and the U.K. longterm corporate bond market virtually disappeared in the second half of the 1970s. Friedman noted that a "proper climate" for growth required "investment, enterprise, the ability to borrow capital” (Dallas Morning News, October 17, 1975), but in the U.K. case he observed that "the domestic capital markets are so disorganized by erratic inflation, excessive taxation, and government intervention" (Newsweek, December 27, 1976).

It was, however, foreign exchange market turmoil that led to the United Kingdom negotiating a loan from the IMF in late 1976. The Callaghan government, including Chancellor of the Exchequer Healey, appealed to the stringent terms of the loan as the reason it had to undertake cuts in government expenditure. Friedman maintained

${ }^{86}$ Milton Friedman Speaks, Episode 5, p. 23 of transcript. that the government's recourse to the IMF was just a charade: "Your government has gone to the IMF so that they can lay down rules for the management of your economy...It's like the way big corporations use management consultants. The corporations know perfectly well what must be done, but they want to blame the unpleasant remedies on someone else" (Daily Mail, September 30, 1976). No doubt there was a considerable element of validity to this conjecture, as senior members of the Callaghan government had indeed accepted the need to shift the division of resources between the public and private sectors. But Friedman went too far with his further claim, "The British government knows that the only way to stop inflation is for government to spend less and to create less money" (Newsweek, October 11, 1976). This claim attributed, yet again, acceptance of a monetary view of inflation to the government. Such an acceptance is not supported by the record of U.K. policymakers' views or behavior; on the contrary, the government continued to point to the Social Contract as a central part of its fight against inflation and to claim that monetary policy alone could not defeat inflation. A wage-push view of U.K. inflation continued to dominate, and the government saw monetary targets-the first publicly announced target was for the financial year starting in April 1976-as a means of helping to avoid adding demand-pull to the wage-push pressures. Friedman subsequently pulled back from his late 1976 claim that the authorities knew inflation was a monetary phenomenon. In a November 7, 1977, talk, Friedman said, "If you listen to anybody telling you about Great Britain's plight, they will tell you that the real problem in Great Britain is that you have such strong trade unions, that they push up wages and that causes inflation." 87

When the government announced its budgetary program in the wake of the IMF loan negotiation, Friedman pronounced himself unimpressed, pointing to the modest nature of the public expenditure cuts, the use of devices such as asset sales, and the failure to cut tax rates (Daily Mail, December 17, 1976). But the U.K. government's expenditure did fall substantially after 1976 as a

\footnotetext{
${ }^{87}$ Milton Friedman Speaks, Episode 6, p. 6 of transcript.
} 
share of output. Acknowledging this, Friedman said in February 1978 that a "rather curious reason for hope" was the fact that a "Labour Government for two years in a row has been led by political pressures to reduce government spending as a fraction of income." 88

Another source of hope for Friedman was a speech that Prime Minister Callaghan made on September 28, 1976. The speech, written with the assistance of Peter Jay (who, as well as being an advocate of money supply control, was Callaghan's son-in-law), was widely interpreted as signaling a repudiation of fine-tuning and Keynesian demand management, and invoked elements of the natural rate hypothesis. Friedman quoted the speech in his Newsweek column (December 6, 1976) and in his Nobel lecture given in December 1976 (Friedman, 1977a). Truth to tell, Friedman cited the speech excessively ${ }^{89}$ and exaggerated its significance. The speech was not so dramatic a break with the past. The fact is that there were many occasions since the 1950s when prime ministers had talked about inflation moving up together with unemployment and on the danger of overstimulating the economy. Callaghan's speech sidestepped the greater problem with U.K. policymakers' outlook on inflation, namely their appeal to nonmonetary explanations.

Friedman appeared on BBC television in late 1976, in a studio debate taped in Chicago with former Wilson government adviser and minister Thomas Balogh. In the debate, Balogh said, "I think that the Professor really is terribly naïve." Friedman responded, "Well, I may be naïve but let me point out first that Mr. Balogh is simply defending his own record. Britain is in the position that it is because it listened to his advice and the advice of people who believe the way he does." Friedman emphasized that he was not referring only to the Labour governments with which Balogh had been affiliated, but to postwar governments of both parties, which he said had "generally followed very much the same policies...I am trying

\footnotetext{
${ }^{88}$ Milton Friedman Speaks, Episode 7, pp. 20-21 of transcript.

${ }^{89}$ For example, in Free to Choose (both the television and book versions), in Milton Friedman Speaks, in Friedman (1992, 1997), etc.
}

to argue against the general drift that has affected both parties" (BBC1, December 6, 1976).

"That great prophet of monetarism, Milt [sic] Friedman, is coming to Strathclyde University [in Glasgow, Scotland] in April to lecture on inflation," observed The Scotsman's business columnist at the start of 1978 (January 25, 1978). In April 1978, Friedman, now 65 and sometimes describing himself as retired, duly appeared in the home city of Adam Smith to give a lecture and press conference. At his Glasgow appearances, Friedman qualified his praise for the Callaghan government's reduction in the ratio of government spending to GDP with criticism of its extensions of government intervention in the marketplace. He also pronounced himself unimpressed by the practical changes made in U.K. monetary policy. "In Britain, monetary targets have been adopted but have not been kept. Mr. Callaghan has said there will be no fine-tuning, but Mr. Healey has been fine-tuning" (The Scotsman, April 22, 1978).

Another aspect of the U.K. policy framework that was anathema to Friedman was the continued proffering of incomes policies—or in Friedman's (1976b, p. 233) blunt characterization, "general price or wage controls, euphemistically referred to as 'incomes policies"' - as a part of the government's anti-inflation strategy. Friedman had observed early in the U.S. wage/price control experiment (Newsweek, January 31, 1972): "Experience in other countries [beside the United States] suggests that for about a year such controls generally look good; after about two years, they collapse." The incomes policies put in place in the United Kingdom from 1972 to 1979 fell roughly into the pattern Friedman described. Heath's wageprice controls imposed in 1972 suppressed inflationary pressure for about a year before a breakout at the end of 1973 and in early 1974. The Social Contract of the Wilson government was largely violated until a more legally binding version was introduced in July 1975. U.K. inflation then generally declined for three years (1975-78), not two. But monetary policy had been tightened in late 1975 and over 1976; it was only from early 1977 that the government's incomes policies were attempting to push inflation away from the direction implied by monetary policy. The substantial 
monetary stimulus created in 1977 was followed by a collapse of the Social Contract at the end of 1978 and at the beginning of 1979. Shortly afterward, the Callaghan government lost a confidence vote in Parliament and had to hold a general election.

Friedman's travels, interviews, and commentary on current events meant that the FriedmanSchwartz Monetary Trends study of the United States and the United Kingdom was being slowed down. Friedman told an audience in Sheffield, England, in September 1970, "Mrs. Anna Schwartz and I are currently engaged on a comparison of U.S. and U.K. monetary trends...I had initially hoped to present a paper on this work at this seminar, but unfortunately the research did not go rapidly enough" (Friedman, 1971b, p. 151). In both that presentation and in Friedman lectures in the following years (Friedman, 1972c, 1973a), the U.K. coverage was limited mainly to discussions of data plots. Friedman and Schwartz (1972, p. 32) admitted, "Our estimate of the time it would take us to complete the manuscript on monetary trends has been unduly optimistic in the past... $[W]$ e shall refrain from projecting a date for completion." The publication of Schwartz (1975) indicated that progress was being made, and by 1979 the project was edging to the finishing line, with publication projected for sometime in the early 1980s.

\section{Issues}

Common Market Entry. Though he sometimes referred to the "European countries and Britain" (e.g., in Pringle, 2002, p. 22), Friedman usually counted the United Kingdom as part of Europe. In 1948 Friedman referred to "Europe, including England” (New York Times, January 11, 1948) and classed the United Kingdom within Europe or Western Europe on later occasions too, including in Friedman (1958a, p. 510) and Friedman and Schwartz (1982, p. 309). A major issue for the United Kingdom in the 1960s and continuing into the 1970s was whether it should join other major European countries in the European Economic Community (EEC) or Common Market. Friedman reminded people that he played a part in the preparations for "the so-called Coal and Steel Community-a precursor to the Common Market" when he served as an adviser to the Marshall Plan in 1950 (Newsweek, May 24, 1971). In 1967, Friedman warned London newspaper readers not to expect too much of EEC membership. "Membership of the Common Market may or may not be good for Britain, but it is not a necessary part of the solution to Britain's difficulties. Germany in 1948 achieved an economicmiracle policy by decontrol without any Common Market” (Sunday Telegraph, June 25, 1967).

After unsuccessful attempts to negotiate entry in the 1960s, the United Kingdom joined the EEC at the start of 1973. By then, Friedman had expressed concern about the direction of the EEC, in particular the danger that it was "dominated by the notion that it's to serve as the supercentral planning body" for member countries (Vision, April 1972). One of the planning measures undertaken by the EEC also went against Friedman's belief in free trade. "So far as the Common Market is concerned, they have engaged in agricultural protectionism on a large scale, as you say," Friedman observed in April 1978. ${ }^{90}$ "They are making a mistake in doing that." In late 1978, the EEC started to move against something Friedman regarded as one of the few favorable economic policy developments in the 1970s: floating exchange rates. The European Monetary System (EMS) was set up at the end of 1978, to commence in 1979. But, for now, the United Kingdom would not be participating. The Callaghan government had decided to stick to a floating pound.

Democracy. Like Keynes before him, Friedman in his work talked about the damaging effects that inflation could have on the stability of a democracy. For example, Friedman opened his testimony to Congress in May 1959 with the following: "Unless we can achieve both a reasonably stable economy in the short run and a reasonably stable price level in the long run, our free enterprise economy is unlikely to be permitted to survive."91 In further testimony later that year, Friedman said, "Wars aside, the chief economic

\footnotetext{
${ }^{90}$ Milton Friedman Speaks, Episode 8, p. 26 of transcript.
} 
threats to the preservation of a free society have come from the sharp fluctuations...in economic activity and in prices...that have threatened to tear the social fabric asunder." 92 Another theme in his work, central to Friedman (1962a), was the presence of a sizable private sector as a necessary condition for political freedom.

Friedman produced a storm when, in 1976, he made use of these two themes to discuss the state of the United Kingdom. On Meet the Press (October 24, 1976), Friedman said, "Great Britain is another horrible example...Britain is on the verge of collapse." Around the same time, Encounter magazine published an article by Friedman, arguing that the public sector had become so large a fraction of the U.K. economy that democracy was threatened: "I fear very much that the odds are at least 50-50 that within the next five years British freedom and democracy, as we have seen it, will be destroyed." 93 The controversy intensified when Friedman made similar remarks in a 60 Minutes special on the U.K. economy broadcast in the United States on November 28.

Friedman's observations produced a backlash in the U.K. press. The Daily Mirror called Friedman the "smiling man of woe," and an editorial criticized his "biased view" and "doomsday solutions" (November 30, 1976a and 1976b). The Daily Express (November 30, 1976) said that Friedman's "sensible followers in this countryparticularly Mrs. Thatcher and Sir Keith Josephmust be in near despair" about his "absurdities." John Kenneth Galbraith joined in the criticism, observing, "If the economists were right every time they predicted a country was going down the drain, there would be nowhere left" (Daily Mirror, January 10, 1977).

The criticism that prompted Friedman to react came from Samuel Brittan. Brittan published an open letter to Friedman in his Financial Times column, arguing that his "recent warnings about the United Kingdom...represent personal hunches,

\footnotetext{
${ }^{91}$ Friedman, May 25, 1959, testimony in Joint Economic Committee (1959a, p. 605; p. 136 of reprint).

92 October 30, 1959, testimony, in Joint Economic Committee (1959b, p. 3020).

${ }^{93}$ Friedman (1976c, p. 9); also published in Sunday Telegraph, October 31, 1976.
}

individual value judgments or exaggerations" that could detract from Friedman's insights on monetary matters (Financial Times, December 2, 1976). Friedman in turn had an "Open Reply" to Brittan defending his statements (Financial Times, January 6, 1977).

This backlash against Friedman's warnings reflected a certain inconsistency on the part of U.K. commentators. A substantial number of U.K. leaders and U.K. economists had made comments similar to Friedman's about the threat to democracy coming from economic instability. For example, in a September 1976 television interview, Prime Minister Callaghan had said, "If we were to fail, I don't think another government could succeed. I do not think that would mean a National [coalition] government. I fear it would lead to a totalitarian government of the Left or the Right" (The Sun, October 1, 1976). An economist at the Bank of England, Charles Goodhart, had warned (1975, p. 221) that continued stagflation of the sort the Western economies had faced in the 1970s "may well serve to destroy the atomistic, democratic, capitalist structure of their existing system."

One element that contributed to the controversy was Friedman's emphasis on the threat to democracy from a large government sector rather than from inflation alone. Friedman was not, however, conflating the issues; he explicitly maintained that excessive growth of government did social harm even if it were not accompanied by inflation. "Ending inflation, in my opinion," Friedman said in 1981, "is a very desirable thing to do. In my opinion, it is likely to be a necessary precondition for resolving the other problems that countries have, but it is not a be-all and end-all of economic policy" (Evening Post, April 27, 1981). In particular, Friedman contended that an inexorable rise in the government spending share of GDP, "even if were accomplished without any inflation whatever...would ultimately destroy our freedom and society" (Evening Capital, November 18, 1978). ${ }^{94}$

It was Friedman's discussion of the U.K. government-to-GDP share that became the matter for which a number of commentators took him to task.

\footnotetext{
${ }^{94}$ A prior occasion on which Friedman separated the issues of inflation and the "threat to the maintenance of a free society" from a large public sector was in a letter to The Economist (September 28, 1974).
} 
The figure he used in Friedman (1976c) and elsewhere of 60 percent was indeed the figure reported by U.K. government publications as of early 1976. But revisions during the year exposed doublecounting, and the official estimate was revised to about 45 percent to 47 percent. Chancellor Healey said that the corrected number refuted "the picture of a profligate public sector as ignorantly presented by Professor Milton Friedman" (House of Commons Debates, November 30, 1976, p. 715). Some discussions, such as Begg (1987) and Tomlinson (1990), mention Friedman's use of the 60 percent figure and create the impression that, had the corrected number been known from the start, there would have been no basis for Friedman's warnings about public expenditure in the United Kingdom. This is questionable; for one thing, Friedman stressed that his argument did not rest on the present number being as high as 60 percent (BBC1, December 6, 1976). For another, Friedman would likely not have agreed with all the statistical decisions used to reach the 45 percent to 47 percent share.

Friedman likely would have insisted that subsidies to firms and transfer payments to individuals be counted in the government spending aggregate, and not (as is often the practice) as "negative taxes." My suspicion is that an estimate that classed these items as spending-and which was sure to include all government enterprises in the government-spending estimate-would show the share peaking above 50 percent during the mid-1970s.

The Thatcher Government. "It's not my job to persuade people about things," Friedman argued (Omaha World-Herald, October 20, 1976; "I just develop ideas and leave them around for people to pick up." Among those seen as picking up Friedman's ideas in the late 1970s was Margaret Thatcher, who had replaced Edward Heath as Conservative Party leader in February 1975. Some have claimed that Thatcher had monetarist ideas even in the late 1960s (Wapshott and Brock, 1983, pp. 88, 187). But the Thatcher statements offered as evidence on this point are similar to those common among politicians at the time-that is, she urged giving monetary policy greater weight among the tools used for demand management. The monetarist view of inflation was not present in Thatcher's 1960s' statements. But there is no doubt that the position on inflation taken by Thatcher and other senior Opposition personnel converged in the late 1970s toward the familiar monetarist one, and that the policy framework of the Conservative Party on returning to office in 1979 was shaped by the monetarist position on inflation. Friedman himself is said to have first had detailed conversations with Thatcher in 1978 (Campbell, 2000, p. 372). These probably took place during his April 1978 visit to the United Kingdom.

Friedman, as discussed previously, was critical of the U.K. Conservative Party's historical record on economic policymaking. The impact of his ideas on Conservative Party policy formation after 1975 did not come in for universal welcome on the part of conservatives in the United Kingdom. The most well-known critics were Edward Heath and other Conservative Party advocates of incomes policy to fight inflation. ${ }^{95}$

But the economic substance of Friedman's arguments was nonpartisan. As early as 1968, Robert Solow noted, "the association of monetarism with right-wing politics is not at all necessary" (The Times, December 23, 1968). Friedman's own observations were in emphatic agreement with Solow's assessment. For example, Friedman (1978) argued: "No doubt there are strong ideological elements in the susceptibility of individuals, including politicians and their advisors, to persuasion by either the monetarist or Keynesian views. Yet the basic issue is scientific, not ideological...Whatever a man's objectives, whatever his ideology, he can pursue them more intelligently the better he understands how the world works."

A specific scientific question underlay much of the U.K. political debate from 1974 onward. The issue was whether incomes policy was a valid weapon against inflation or whether instead only monetary policy could accomplish disinflation. The outcome of this debate rested on the scientific question of whether inflation

\footnotetext{
${ }^{95}$ The projected companion paper covering 1979-2006 will deal in detail with Heath's disagreements with Friedman, including those covered in their radio debate in 1980.
} 
was a monetary phenomenon. One Laboursupporting writer recognized the scientific aspect to the debate in 1974, observing: "There is a danger that socialists will dismiss the monetarists' argument simply because that school of thought has hitherto been associated with right-wing conservatism. This is because the leading monetarist, Professor Milton Friedman, has some very eccentric right-wing views. But, in fact, the analysis of the rate of inflation is in no way related to ideological conservatism...Socialists will have to come to terms with this school of thought if we are to effectively fight inflation" (New Statesman, October 25, 1974).

Governments of both political parties in the United Kingdom eventually assigned inflation control to monetary policy. This reflected not the triumph of ideology, but the fact that policymakers wanted inflation down, and had accepted that, as a technical matter, the only way this could be accomplished was through monetary policy. As Friedman put it, "It's not what I advocate that matters; there is only one way to do it" (St. Louis Globe-Democrat, December 16, 1977).

That convergence of the political parties' positions had not yet occurred when the 1979 U.K. general election was held. The Callaghan government went to the election with incomes policy prominent in its platform, including a new union/government agreement on wages to replace the Social Contract, and plans to extend price control, while the Conservative Party under Thatcher rejected incomes policy in favor of a focus on monetary control. Interviewed by BBC television several months after Thatcher's election victory, Friedman underlined the change in direction, both with respect to monetary policy and to the role of government, implied by Thatcher's coming to power. "If the Thatcher government succeeds," Friedman said, "it will be an example that will not be lost on the United States or the rest of the world." 96

\section{CONCLUSION}

The U.K. banking periodical Midland Bank Review commented in its Summer 1979 issue on the implications of the change of government for the direction of economic policy. "The mantle of Keynes, and particularly the embroideries of his followers, appears to have worn thin; and the mode has shifted towards the sterner lines of thought popularized by Milton Friedman. The new Government comes to office in a climate of opinion very different from that which influenced its Conservative predecessor." Nevertheless, Nicholas Kaldor was able to boast accurately that Friedman had "made comparatively few converts among academic economists" in the United Kingdom. ${ }^{97}$ The support for Friedman's ideas was also thin among members of the new government, once one looked below the most senior levels. In these circumstances, and despite his drawing of distinctions between his own positions and those of the Thatcher government, Friedman would find himself a central figure in the debate over the new economic policies. In 1979 he was about to shift to an even-higher profile in the United Kingdom and, in defending his positions on monetary policy and on the role of government, would encounter in debate some of the most formidable figures in U.K. economics and some of the biggest names in both major political parties.

\section{REFERENCES*}

Anderson, Martin, ed. Registration and the Draft: Proceedings of the Hoover-Rochester Conference on the All-Volunteer Force. Stanford, CA: Hoover Institution Press, 1982.

Beenstock, Michael. A Neoclassical Analysis of Macroeconomic Policy. Cambridge, UK: Cambridge University Press, 1980.

Begg, David. “U.K. Fiscal Policy Since 1970,” in Richard Layard and Rudiger Dornbusch, eds., The Performance of the British Economy. Oxford, UK: Oxford University Press, 1987, pp. 29-63.

\footnotetext{
${ }^{96}$ October 11, 1979, broadcast of interview with Friedman on BBC television program Newsweek.

${ }^{97}$ Kaldor (1982, p. xxii).

* Sources for periodical articles and television appearances/ interviews are listed in the Bibliographical Appendix.
} 


\section{Nelson}

Benati, Luca. "The Inflation-Targeting Framework from an Historical Perspective." Bank of England Quarterly Bulletin, Summer 2005, 45(2), pp. 160-68.

Bernanke, Ben S. "Friedman's Monetary Framework: Some Lessons," in Mark A. Wynne, Harvey Rosenblum, and Robert L. Formaini, eds., The Legacy of Milton and Rose Friedman's Free to Choose: Economic Liberalism at the Turn of the 21st Century. Dallas, TX: Federal Reserve Bank of Dallas, 2004, pp. 207-17.

Blinder, Alan S. "Ruminations on Karl Brunner's Reflections," in R.W. Hafer, ed., The Monetary Versus Fiscal Policy Debate: Lessons from Two Decades. Totowa, NJ: Rowman and Allanheld, 1986, pp. 117-26.

Bordo, Michael D. and Wheelock, David C. "Monetary Policy and Asset Prices: A Look Back at Past U.S. Stock Market Booms." Federal Reserve Bank of St. Louis Review, November/December 2004, 86(6), pp. 19-44; http://research.stlouisfed.org/publications/ review/04/11/BordoWheelock.pdf.

Brunner, Karl. "Confusion of Language and the Politics of Uncertainty." Shadow Open Market Committee Position paper, University of Rochester, March 24-25, 1985.

Brunner, Karl and Meltzer, Allan H. Money and the Economy: Issues in Monetary Analysis. Cambridge, UK: Cambridge University Press, 1993.

Cairncross, Alec. The Wilson Years: A Treasury Diary, 1964-1969. London: Historian's Press, 1997.

Campbell, John. Margaret Thatcher. Volume 1: The Grocer's Daughter. London: Jonathan Cape, 2000.

Capie, Forrest and Webber, Alan. A Monetary History of the United Kingdom, 1870-1982. Volume I: Data, Sources, Methods. London: Allen and Unwin, 1985.

Childs, Bruce. Britain Since 1945: A Political History. Sixth Edition. London: Routledge, 2006.

Cobham, David. "Convergence, Divergence and Realignment in British Macroeconomics." Banca Nazionale del Lavoro Quarterly Review, June 1984, 149, pp. 159-76.
Committee on Banking and Currency, House of Representatives. The Federal Reserve System After Fifty Years. Washington, DC: Government Printing Office, 1964.

Committee on the Budget, House of Representatives. Second Budget Resolution: Fiscal Year 1976.

Washington, DC: Government Printing Office, 1975.

Committee on the Judiciary, House of Representatives. Constitutional Amendments to Balance the Federal Budget: Hearings. Washington, DC: Government Printing Office, 1980.

Dacey, W. Manning. "The Cheap Money Technique.” Lloyds Bank Review, January 1947, 2(1), 49-63.

Edge, Stephanie K. "The Relative Stability of Monetary Velocity and the Investment Multiplier." Australian Economic Papers, December 1967, 6(9), pp. 192-207.

Eshag, Eprime. Fiscal and Monetary Policies and Problems in Developing Countries. Cambridge, UK: Cambridge University Press, 1983.

Friedman, Milton. "The Inflationary Gap: II. Discussion of the Inflationary Gap." American Economic Review, February 1942, 32(2), pp. 314-20.

Friedman, Milton. "Methods of Predicting the Onset of 'Inflation,'” in Carl S. Shoup, Milton Friedman, and Ruth P. Mack, eds., Taxing to Prevent Inflation. New York: Columbia University Press, 1943, pp. 111-53.

Friedman, Milton. "Book Review: Saving, Investment and National Income by Oscar L. Altman.” Review of Economics and Statistics, May 1944, 26(2), pp. 101-02.

Friedman, Milton. "A Monetary and Fiscal Framework for Economic Stability.” American Economic Review, June 1948, 38(3), pp. 245-64.

Friedman, Milton. "Wesley Mitchell as an Economic Theorist." Journal of Political Economy, December 1950, 58(6), pp. 465-93.

Friedman, Milton. "Some Comments on the Significance of Labor Unions for Economic Policy," 
in David McCord Wright, ed., The Impact of the Union. New York: Harcourt Brace, 1951, pp. 204-34.

Friedman, Milton. "Price, Income and Monetary Changes in Three Wartime Periods." American Economic Review, May 1952 (Papers and Proceedings), 42(2), pp. 612-25.

Friedman, Milton. Essays in Positive Economics. Chicago: University of Chicago Press, 1953a.

Friedman, Milton. "The Case for Flexible Exchange Rates," in Essays in Positive Economics. Chicago: University of Chicago Press, 1953b, pp. 157-203.

Friedman, Milton. "Why the American Economy Is Depression Proof." Nationalekonomiska föreningens förhandlingar (Stockholm), 1954, 3, pp. 58-77. Reprinted in Milton Friedman, Dollars and Deficits: Inflation, Monetary Policy and the Balance of Payments. Englewood Cliffs, NJ: Prentice Hall, 1954, pp. 72-96.

Friedman, Milton. "Money and Banking,” in Solomon Fabricant, ed., Government in Economic Life: National Bureau of Economic Research Thirty-Fifth Annual Report, May 1955. New York: NBER, 1955, pp. 30-33.

Friedman, Milton. "The Quantity Theory of Money: A Restatement," in Milton Friedman, ed., Studies in the Quantity Theory of Money. Chicago: University of Chicago Press, 1956, pp. 3-21.

Friedman, Milton. "Foreign Economic Aid: Means and Objectives." Yale Review, June 1958a, 47(4), pp. 500-16.

Friedman, Milton. "What Price Inflation?" Finance and Accounting, 1958b, 38(7), pp. 18-27.

Friedman, Milton. "Book Review: Inflation by Thomas Wilson." American Economic Review, December 1961a, 51(5), pp. 1051-55.

Friedman, Milton. "Monetary Data and National Income Estimates." Economic Development and Cultural Change, April 1961b, 9(3), pp. 267-86.

Friedman, Milton. Capitalism and Freedom. Chicago: University of Chicago Press, 1962a.
Friedman, Milton. "Is a Free Society Stable?" New Individualist Review, Summer 1962b, 2(2), pp. 3-10.

Friedman, Milton. Inflation: Causes and Consequences. Bombay: Asia Publishing House, 1963a.

Friedman, Milton. "The Present State of Monetary Theory," Economic Studies Quarterly, September 1963b, 14(1), 1-15.

Friedman, Milton. "Postwar Trends in Monetary Theory and Policy." National Banking Review, September 1965a, 2(1), pp. 1-9. Reprinted in Milton Friedman, The Optimum Quantity of Money and Other Essays. Chicago: Aldine, 1969, pp. 69-79.

Friedman, Milton. "The Monetary Studies of the National Bureau," in The National Bureau Enters Its 45th Year, 44th Annual Report of the National Bureau of Economic Research. New York: NBER, 1964b, pp. 7-25. Reprinted in Milton Friedman, The Optimum Quantity of Money and Other Essays. Chicago: Aldine, 1969, pp. 261-83.

Friedman, Milton. "Discussion." American Economic Review, March 1965, 55(1/2), pp. 178-81.

Friedman, Milton. Dollars and Deficits: Inflation, Monetary Policy and the Balance of Payments. Englewood Cliffs, NJ: Prentice Hall, 1968a.

Friedman, Milton. "The Role of Monetary Policy." American Economic Review, March 1968b, 58(1), pp. 1-17.

Friedman, Milton. “Money: Quantity Theory,” in David L. Sills, ed., International Encyclopedia of the Social Sciences. Volume 10. New York: Macmillan, 1968c, pp. 432-47.

Friedman, Milton. "The International Adjustment Mechanism: Panel Discussion," in Federal Reserve Bank of Boston, The International Adjustment Mechanism. Boston: Federal Reserve Bank of Boston, 1969; pp. 15-20.

Friedman, Milton. "The Counter-Revolution in Monetary Theory.” IEA Occasional Paper No. 33, Institute of Economic Affairs, 1970a. Reprinted in 
Milton Friedman, Monetarist Economics. Oxford, UK: Basil Blackwell, 1991; pp. 1-20.

Friedman, Milton. "Comment on Tobin.” Quarterly Journal of Economics, May 1970b, 84(2), pp. 318-27.

Friedman, Milton. "The New Monetarism: Comment." Lloyds Bank Review, October 1970c, 25(98), pp. 52-53.

Friedman, Milton. "Government Revenue from Inflation." Journal of Political Economy, July/August 1971a, 79(4), pp. 346-56.

Friedman, Milton. "A Note on the U.S. and U.K. Velocity of Circulation,” in George Clayton, John C. Gilbert, and Robert C. Sedgwick, eds., Monetary Theory and Monetary Policy in the 1970s: Proceedings of the 1970 Sheffield Money Seminar. London: Oxford University Press, 1971b, pp. 151-52.

Friedman, Milton. "Comments on the Critics," Journal of Political Economy, September/October 1972a, 80(5), pp. 906-50.

Friedman, Milton. "Monetary Policy," in Proceedings of the American Philosophical Society, June 1972b, 116(3), pp. 183-96.

Friedman, Milton. "Monetary Trends in the United States and United Kingdom." American Economist, Spring 1972c, 16(1), pp. 4-17.

Friedman, Milton. "Have Monetary Policies Failed?" American Economic Review, May 1972d (Papers and Proceedings), 62(2), pp. 11-18.

Friedman, Milton. Money and Economic Development: The Horowitz Lectures of 1972. New York: Praeger, 1973a.

Friedman, Milton. "Facing Inflation." Challenge, November 1973b, 16(5), 29-37.

Friedman, Milton. "Monetary Correction.” IEA Occasional Paper No. 41, Institute of Economic Affairs, 1974. Reprinted in Milton Friedman, Monetarist Economics. Oxford, UK: Basil Blackwell, 1991, pp. 21-47.
Friedman, Milton. There's No Such Thing As a Free Lunch: Essays on Public Policy. LaSalle, IL: Open Court, 1975a.

Friedman, Milton. "25 Years after the Rediscovery of Money: What Have We Learned? Discussion.” American Economic Review, May 1975b (Papers and Proceedings), 65(2), pp. 176-79.

Friedman, Milton. Milton Friedman in Australia 1975. Darlinghurst, NSW: Dryden Press, 1975c.

Friedman, Milton. Is Inflation a Curable Disease? Alex C. Walker Memorial Lecture, December 1974. Pittsburgh: University of Pittsburgh Graduate School of Business, 1975d.

Friedman, Milton. "Foreword," in Fritz Machup, ed., Essays on Hayek. New York: New York University Press, 1976a, pp. xxi-xxiv.

Friedman, Milton. Price Theory. Second Edition. Chicago: Aldine, 1976b.

Friedman, Milton. "The Line We Dare Not Cross." Encounter, November 1976c, 47(5), pp. 8-14.

Friedman, Milton. "Nobel Lecture: Inflation and Unemployment.” Journal of Political Economy, June 1977a, 85(3), 451-72.

Friedman, Milton. "Discussion of 'The Monetarist Controversy.", Federal Reserve Bank of San Francisco Economic Review, Spring 1977b, (Suppl.), pp. 12-26.

Friedman, Milton. "How Stands the Theory and Practice of Monetary Policy?” Presented at the Mont Pelerin Society meeting, Hong Kong, 1978.

Friedman, Milton. "Memorandum: Response to Questionnaire on Monetary Policy, June 11, 1980," in Treasury and Civil Service Committee, Memoranda on Monetary Policy. London: H.M.S.O, 1980a, pp. 55-61.

Friedman, Milton. "Comment on Benjamin M. Friedman, "The Changing Character of Financial Markets,", in Martin Feldstein, ed., The American Economy in Transition. Chicago: University of Chicago Press, 1980b, pp. 78-86. 
Friedman, Milton. On Milton Friedman. Vancouver, BC: Fraser Institute, 1982a.

Friedman, Milton. "Monetary Policy: Theory and Practice." Journal of Money, Credit, and Banking, February 1982b, 14(1), pp. 98-118.

Friedman, Milton. "Monetarism in Rhetoric and Practice." Bank of Japan Monetary and Economic Studies, October 1983, 1(2), pp. 1-14.

Friedman, Milton. "Quantity Theory of Money,” in John Eatwell, Murray Milgate, and Peter Newman, eds., The New Palgrave: A Dictionary of Economics, Volume 4, Q to Z. London: Macmillan, 1987, pp. 3-20.

Friedman, Milton. "A Proposal for Resolving the U.S. Balance of Payments Problem: Confidential Memorandum to President-Elect Nixon [1968]," in L. Melamed, ed., The Merits of Flexible Exchange Rates: An Anthology. Fairfax, VA: George Mason University Press, 1988, pp. 429-38.

Friedman, Milton. Money Mischief: Episodes in Monetary History. New York: Harcourt Brace Jovanovich, 1992.

Friedman, Milton. "The 'Plucking Model' of Business Fluctuations Revisited.” Economic Inquiry, April 1993, 31(2), pp. 171-77.

Friedman, Milton. “John Maynard Keynes.” Federal Reserve Bank of Richmond Economic Quarterly, Spring 1997, 83(2), pp. 1-23.

Friedman, Milton. "Comment: Inflation, Unemployment and the Pound," in Subroto Roy and John Clarke, eds., Margaret Thatcher's Revolution: How It Happened and What It Meant. London: Continuum, 2005, p. 66.

Friedman, Milton and Friedman, Rose D. Free to Choose. New York: Harcourt Brace Jovanovich, and Middlesex, UK: Penguin, 1980.

Friedman, Milton and Friedman, Rose D. Two Lucky People: Memoirs. Chicago: University of Chicago Press, 1998.
Friedman, Milton and Meiselman, David. "The Relative Stability of Monetary Velocity and the Investment Multiplier in the United States, 18971958," in Commission on Money and Credit, ed., Stabilization Policies. Eaglewood Cliffs, NJ: Prentice Hall, 1963, pp. 165-268.

Friedman, Milton and Roosa, Robert V. The Balance of Payments: Free Versus Fixed Exchange Rates. Washington, DC: American Enterprise Institute, 1967.

Friedman, Milton and Schwartz, Anna J. A Monetary History of the United States, 1867-1960. Princeton, NJ: Princeton University Press, 1963.

Friedman, Milton and Schwartz, Anna J. Trends in Money, Income, and Prices, 1867-1966 [manuscript version]. New York: National Bureau of Economic Research, 1966.

Friedman, Milton and Anna J. Monetary Statistics of the United States. New York: Columbia University Press, 1970.

Friedman, Milton and Schwartz, Anna J. "Money," in Innovations in Economic Research, 52nd Annual Report of the National Bureau of Economic Research, September 1972. New York: NBER, 1972, pp. 29-32.

Friedman, Milton and Schwartz, Anna J. Monetary Trends in the United States and the United Kingdom: Their Relation to Income, Prices, and Interest Rates, 1867-1975. Chicago: University of Chicago Press, 1982.

Goodhart, Charles A. E. Money, Information and Uncertainty. London: Macmillan, 1975.

Gurley, John G. and Shaw, Edward S. Money in a Theory of Finance. Washington, DC: Brookings Institution, 1960.

Hallowell, Burton C. A Study of British Interest Rates, 1929-50. Philadelphia: Connecticut General Life Insurance Company, 1950.

Harrod, Roy."Discussion Papers: (a) Sir Roy Harrod," in George Clayton; John C. Gilbert; John C. and Robert C. Sedgwick, eds., Monetary Theory and Monetary Policy in the 1970s: Proceedings of the 


\section{Nelson}

1970 Sheffield Money Seminar. London: Oxford University Press, 1971, pp. 58-63.

Institute of Economic Affairs. Inflation: Causes, Consequences, and Cures. London: Institute of Economic Affairs, 1974.

Johnson, Harry G. "Review: Money and Economic Development." Economica, August 1974, 41(163), 346-347.

Joint Committee on the Economic Report. Monetary Policy and the Management of the Public Debt: Replies to Questions. Washington, DC: Government Printing Office, 1952.

Joint Economic Committee. Employment, Growth, and Price Levels, Hearings, Part 4. Washington, DC: Government Printing Office, 1959a. Friedman's opening testimony reprinted as Milton Friedman, "Monetary Theory and Policy," in R.J. Ball and Peter Doyle, eds., Inflation. London: Penguin, 1969, pp. 136-45.

Joint Economic Committee. Employment, Growth, and Price Levels, Hearings. Part 9A. Washington, DC: Government Printing Office, 1959b.

Joint Economic Committee. The United States Balance of Payments: Hearings. Part 3. Washington, DC: Government Printing Office, 1963.

Joint Economic Committee. Economic Analysis and the Efficiency of Government: Hearings. Part 3. Washington, DC: Government Printing Office, 1970.

Joint Economic Committee. The President's New Economic Program: Hearings. Part 3. Washington, DC: Government Printing Office, 1971.

Joint Economic Committee. The Supersonic Transport: Hearings. Washington, DC: Government Printing Office, 1973a.

Joint Economic Committee. How Well Are Fluctuating Exchange Rates Working? Hearings. Washington, DC: Government Printing Office, 1973b.

Kaldor, Nicholas. "The New Monetarism.” Lloyds Bank Review, July 1970, 25(97), pp. 1-18.
Kaldor, Nicholas. The Scourge of Monetarism. Oxford, UK: Oxford University Press, 1982.

Keynes, John Maynard. The General Theory of Employment, Interest and Money. London: Macmillan, 1936.

Keynes, John Maynard. How to Pay for the War: A Radical Plan for the Chancellor of the Exchequer. London: Macmillan, 1940.

Krugman, Paul. "It's Baaack! Japan’s Slump and the Return of the Liquidity Trap." Brookings Papers on Economic Activity, 1998, 29(2), pp. 137-87.

Laidler, David. "Radcliffe, the Quantity Theory and Monetarism," in David Cobham; Richard Harrington, and George Zis, eds., Money, Trade, and Payments: Essays in Honour of D.J. Coppock. Manchester, UK: Manchester University Press, 1989, pp. 17-37.

Laidler, David. "From Bimetallism to Monetarism: The Shifting Political Affiliation of the Quantity Theory." Research Report 2001-1, Department of Economics, University of Western Ontario, 2001.

Laidler, David. "The Role of the History of Economic Thought in Modern Macroeconomics," in Paul Mizen, ed., Modern History, Exchange Rates and Financial Markets: Essays in Honour of Charles Goodhart. Volume Two. Cheltenham, UK: Edward Elgar, 2003, pp. 12-29.

Levy, David. "Milton Friedman: Interview.” Federal Reserve Bank of Minneapolis The Region, June 1992, 6(2), pp. 6-13.

Lindsey, David E.; Orphanides, Athansios and Rasche, Robert H. "The Reform of October 1979: How It Happened and Why." Federal Reserve Bank of St. Louis Review, March/April 2005, 87(2 Part 2), pp. 187-235; http://research.stlouisfed.org/ publications/review/05/03/part2/Lindsey.pdf.

London and Cambridge Economic Service. Key Statistics of the British Economy, 1900-1962. London: Leagrave Press, 1963.

Mankiw, N. Gregory. "The Inexorable and Mysterious Tradeoff between Inflation and Unemployment." Economic Journal, May 2001, 111(471), pp. C45-C61. 
Marty, Alvin L. "Gurley and Shaw on Money in a Theory of Finance," Journal of Political Economy, February 1961, 69(1), pp. 56-62.

Meltzer, Allan H. "Monetarist, Keynesian and Quantity Theories." Kredit und Kapital, June 1977, 10(2), pp. 149-82. Reprinted in Thomas Mayer; Martin Bronfenbrenner; Karl Brunner et al., The Structure of Monetarism. New York: W.W. Norton, 1978, pp. 145-75.

Modigliani, Franco. The Debate Over Stabilization Policy. Cambridge, UK: Cambridge University Press, 1986.

Nelson, Edward. "An Overhaul of Doctrine: The Underpinning of U.K. Inflation Targeting.” Economic Journal, June 2009, 119(538), pp. F333-68.

Nelson, Edward and Schwartz, Anna M. "The Impact of Milton Friedman on Modern Monetary Economics: Setting the Record Straight on Paul Krugman's 'Who Was Milton Friedman?'” Journal of Monetary Economics, May 2008, 55(4), pp. 835-56.

Oxford University Press. Oxford English Dictionary. Oxford, UK: Clarendon Press, 1976.

Patinkin, Don. "An Indirect-Utility Approach to the Theory of Money, Assets and Savings," in Frank H. Hahn and Frank P.R. Brechling, eds., Theory of Interest Rates: Proceedings of a Conference Held by the International Economic Association. London: Macmillan, 1965.

Patinkin, Don. "The Chicago Tradition, the Quantity Theory, and Friedman." Journal of Money, Credit, and Banking, February 1969, 1(1), pp. 46-70.

Patinkin, Don. "Friedman on the Quantity Theory and Keynesian Economics." Journal of Political Economy, September/October 1972a, 80(5), pp. 883-905.

Patinkin, Don. "On the Short-Run Non-Neutrality of Money in the Quantity Theory." Banca Nazionale del Lavoro Quarterly Review, March 1972b, 100, pp. 3-22.
Patinkin, Don. Keynes' Monetary Thought: A Study of Its Development. Durham, NC: Duke University Press, 1976a.

Patinkin, Don. "Keynes and Econometrics: On the Interaction Between the Macroeconomic Revolutions of the Interwar Period.” Econometrica, November 1976b, 44(6), pp. 1091-1123.

Pringle, Robert. "Interview: Milton Friedman." Central Banking, August 2002, 13(1), pp. 15-23.

Radcliffe Committee. Committee on the Working of the Monetary System: Report. London, UK: HMSO, 1959.

Radcliffe Committee. Minutes of Evidence: Committee on the Working of the Monetary System. London: HMSO, 1960.

Robertson, D.H. "What Has Happened to the Rate of Interest?” Three Banks Review, March 1949, 1(1), pp. 15-31.

Samuelson, Paul A. "Lord Keynes and the General Theory.” Econometrica, July 1946, 14(3), pp. 187-200.

Schlesinger, James R. "After Twenty Years: The General Theory.” Quarterly Journal of Economics, November 1956, 70(4), pp. 581-602.

Schwartz, Anna J. "Why Money Matters.” Lloyds Bank Review, October 1969, 24(94), pp. 1-16.

Schwartz, Anna J. "Monetary Trends in the United States and the United Kingdom, 1878-1970: Selected Findings." Journal of Economic History, March 1975, 35(1), pp. 138-59.

Selden, Richard T., ed. Capitalism and Freedom: Problems and Prospects; Proceedings of a Conference in Honor of Milton Friedman. Charlottesville, VA: University Press of Virginia, 1975.

Snowdon, Brian; Vane, Howard R. and Wynarczyk, Peter. "Interview: Milton Friedman," in A Modern Guide to Macroeconomics: An Introduction to Competing Schools of Thought. Aldershot, UK: Edward Elgar, 1994, pp. 171-78. 


\section{Nelson}

Snowdon, Brian and Vane, Howard R. "Modern Macroeconomics and Its Evolution from a Monetarist Perspective: An Interview with Professor Milton Friedman." Journal of Economic Studies, July/ August 1997, 24(4), pp. 192-222.

Solow, Robert M. Price Expectations and the Behavior of the Price Level. Manchester, UK: Manchester University Press, 1969.

Svensson, Lars E. O. "Escaping from a Liquidity Trap and Deflation: The Foolproof Way and Others." Journal of Economic Perspectives, Fall 2003, 17(4), 145-66.

Tomlinson, Jim. Public Policy and the Economy Since 1900. Oxford, UK: Oxford University Press, 1990.

Walters, Alan A. "The Radcliffe Report-Ten Years After: A Survey of Empirical Evidence," in David R. Croome and Harry G. Johnson, eds., Money in
Britain, 1959-1969. Oxford, UK: Oxford University Press, 1970, pp. 39-68. Reprinted in Kent Matthews, ed., The Economics and Politics of Money: The Selected Essays of Alan Walters. Glouchestershire, UK: Edward Elgar, 1998, pp. 91-120.

Wapshott, Nicholas and Brock, George. Thatcher. London: Macdonald, 1983.

Wilson, Harold. Final Term: The Labour Government, 1974-1976. London: Weidenfeld and Nicolson, 1979.

Wilson, Thomas. "Monetarism in Britain," in Thomas Wilson, Inflation, Unemployment, and the Market. Oxford, UK: Clarendon Press, 1984, pp. 41-78.

Wright, David McCord, ed. "Selections from the Discussion of Friedman's Paper," in The Impact of the Union: Eight Economic Theorists Evaluate the Labor Union Movement. New York: Harcourt Brace, 1951, pp. 235-59. 


\section{BIBLIOGRAPHICAL APPENDIX*}

\section{Periodical Articles Cited}

“Cripps Attacks the Tory Policy,” News-Chronicle, December 18, 1944, p. 3.

“Government’s ‘Anti-Slump’ Powers,” Financial Times (London), November 23, 1945, p. 1.

"Departmental Deals in Gilt-Edged: 'Net Sellers' in the Past Six Months-Says Chancellor; Danger of Trade Depression Outside U.K.," Financial Times, October 17, 1946, p. 3.

“2 $2 \frac{1}{2} \%$ Rate Dropped: 'Locals’ on 3\% Basis; Other Changes Forecast,” Financial Times, January 3, 1948, p. 1.

Aaron Director, Milton Friedman, Abram L. Harris, Frank H. Knight, H. Gregg Lewis, Lloyd W. Mints, Russell T. Nichols, and W. Allen Wallis, "Control of Prices: Regulation of Money Supply to Halt Inflation Advocated," New York Times, January 11, 1948, p. E8.

Editorial, "Prices," Financial Times, February 10, 1951, p. 4.

Milton Friedman, "Living with the Dollar," The Economist (London), January 3, 1953, p. 16.

A.S., "Bookshelf: The Dollar Grows Up-Mr. Harrod's Lectures," Financial Times, December 21, 1953, p. 10.

P.E., “Shorter Notices: Essays in Positive Economics,” Financial Times, February 8, 1954, p. 8.

Editorial, "Industrial Stocks,” Financial Times, February 15, 1955, p. 6.

P.E., "Some Shorter Notices: John Maynard Keynes—Economist and Policy-Maker by Seymour Harris," Financial Times, May 23, 1955, p. 10.

Harold Wincott, “The Root of the Evil-1. Too Much Money,” Financial Times, October 4, 1955, p. 6. Lombard, “The Fall in Bank Deposits,” Financial Times, November 30, 1955, p. 3.

“Money Market Control,” Manchester Guardian, December 12, 1955, p. 10.

P.E., "Shorter Notices: Introduction to Keynesian Dynamics by Kenneth K. Kurihara,” Financial Times, October 15, 1956, p. 10.

Express Staff Reporter, "Folly to Go On Like This: Thorneycroft Talks of the Facts of Life," Daily Express, July 13, 1957, p. 2.

Andrew Alexander, “A Chancellor Needs a Thick Skin: Mr. Selwyn Lloyd Talks Freely to Andrew Alexander,” Yorkshire Post, July 11, 1962, p. 5.

Milton Friedman, “The View from America: Floating the Pound," Sunday Telegraph (London), June 25, 1967, p. 15.

Paul Bareau, "Inflation Limiting Britain’s Scope,” The Sun (London), October 7, 1968, p. 8

Samuel Brittan, “Money Supply: The Great Debate,” Financial Times, October 25, 1968, p. 16.

Harlow Unger, “The Economic Consequences of Mr. Nixon,” Sunday Times (London), November 10, 1968, p. 36.

Paul A. Samuelson, “Don't Make Too Much of the Quantity Theory," Sunday Telegraph, December 15, 1968, pp. 19 and 21.

Robert M. Solow, "Putting the Money Supply Dispute into Its True Perspective," The Times, December 23, 1968, p. 21.

Alan Day, “Jenkins Goes Chicago-Style,” The Observer (London), April 20, 1969, p. 12.

* Sources in the appendix sections are arranged in chronological order. 


\section{Nelson}

Samuel Brittan, "What the 'New Old' Economics Mean[s]," Financial Times, January 8, 1970, p. 17. Editorial, “The Budget,” The Economist, April 18, 1970, pp. 61-64.

Edward Heath, “A Better Tomorrow: Foreword by Mr. Heath,” The Guardian, May 27, 1970, p. 6.

“Two Decades of Inflation,” The Economist, August 29, 1970, pp. 12-13.

Milton Friedman, “Development Fashions,” Newsweek, December 21, 1970, p. 82.

Editorial, “Heath Means Business,” Dallas Morning News, February 9, 1971, p. 2 D.

Robert McKenzie, "The American Economist Milton Friedman, in Conversation with Robert McKenzie, Gives His View of How Our Economic Problems Could Be Solved,” The Listener (London),

February 11, 1971, pp. 169-171.

Milton Friedman, “Needed: More of the Same,” Newsweek, February 15, 1971, p. 58.

Jack Prosser, “The D-Mark Dollar Crisis...Why Germany Didn’t Wait for the Crunch Again,” Evening

Standard (London), May 5, 1971, p. 47.

Milton Friedman, “The Mark Crisis,” Newsweek, May 24, 1971, p. 72.

Milton Friedman, Paul A. Samuelson, and Henry Wallich, "Three Views of Nixonomics and Where It Leads," Newsweek, January 31, 1972, pp. 74-75.

Richard Howe, “Talking to Vision: M. Friedman-Whatever Happened to Free Enterprise?”Vision (London), April 1972, pp. 41-44.

John McClaughry, “Milton Friedman Responds” (interview), Business and Society Review, No. 1, Spring 1972, pp. 5-16. Reprinted as "A Business and Society Review Interview" in Friedman (1975a, pp. 240-56).

Milton Friedman, “A Cold Day for Britain,” Newsweek, November 27, 1972, p. 87.

Milton Friedman, “Unemployment and Monetary Growth,” The Times, December 12, 1972, p. 17.

Associated Press, “Economist Out of Hospital,” Kansas City Times, December 27, 1972, p. 2A.

Editorial, “The Real Inflation Threat,” Management Today, August 1973, p. 18.

Milton Friedman, "Public Spending and Inflation,” The Times, August 29, 1973, p. 15

Frances Cairncross, "Inflation 'Immoral Tax No M.P. Would Approve,”” The Guardian, September 16, 1974, p. 12.

Milton Friedman, "Economic Policy,” The Economist, September 28, 1974, p. 4.

Paul Whiteley, “The Monetarists and Labour,” New Statesman, October 25, 1974, p. 574.

Milton Friedman, “National Economic Planning,” Newsweek, July 14, 1975, p. 71.

Theodore Kurrus, "Laissez Faire: Friedman Against Government Control,” Dallas Morning News,

October 17, 1975, p. 13B.

Editorial, “Changing Money,” Management Today, August 1976, p. 3.

David Sinclair, “Inflation: “The Tax That Never Has to Be Passed by Parliament,”” The Times,

September 13, 1976, p. 7.

Milton Friedman, "Money and Inflation,” Newsweek, September 20, 1976, p. 77.

Roger Nuttall, "We're Battling for More Than Simply the Pound, We're Battling for Our Very Freedom:

Milton Friedman of the Chicago School of Economics Talking to Roger Nuttall,” Daily Mail,

September 30, 1976.

Roger Carroll, "Grim Jim Warns the Nation-Our Last Chance: 'We Could Have a Dictatorship If This

Government Sinks,”, The Sun, October 1, 1976, pp. 1-2.

Milton Friedman, “The Pound Crisis,” Newsweek, October 11, 1976, p. 91. 
Rob Warden, “Economist Friedman’s Logic Loved, Hated,” Omaha World-Herald, October 20, 1976, p. 44. (Originally in Chicago Daily News.)

Milton Friedman, "What Friedman Really Thinks of Britain,” Sunday Telegraph, October 31, 1976.

Milton Friedman, "High Living as a Tax Shelter," Newsweek, November 8, 1976, p. 80.

Nicholas Davies, “Smiling Man of Woe,” Daily Mirror (London), November 30, 1976a, p. 2.

Editorial, “Mirror Comment: Right On?” Daily Mirror, November 30, 1976b, p. 2.

Editorial, “The Kindest Course?” Daily Express, November 30, 1976, p. 10.

Samuel Brittan, “An Open Letter to Professor Friedman,” Financial Times, December 2, 1976, p. 21.

Milton Friedman, “To Jimmy from James,” Newsweek, December 6, 1976, p. 45.

William Lowther, “Healey’s Budget Won’t Work, Says Friedman,” Daily Mail, December 17, 1976.

Milton Friedman, "How to Denationalize,” Newsweek, December 27, 1976, p. 54.

Editorial, “The Friedman Solution,” Management Today, January 1977, p. 3.

Milton Friedman, “An Open Reply from Milton Friedman,” Financial Times, January 6, 1977, p. 17.

Paul Callan, “Why Dr. Galbraith Thinks Britain Is Great,” Daily Mirror, January 10, 1977, p. 18.

Fred Kutchins, “Leaning against Next Year's Wind” (interview with Milton Friedman), Saturday

Evening Post (New York), May/June 1977, pp. 16 and 18-20.

David M. Grebler, “Friedman Is Optimistic About Public’s Economic Understanding,” St. Louis GlobeDemocrat, December 16, 1977, p. 12C.

George McCarthy, "Column One,” The Scotsman, January 25, 1978, p. 3.

Michael Fry, “Prof. Friedman Scorns Big Seven Summit,” The Scotsman, April 22, 1978, p. 5.

Milton Friedman, “Has the Tide Turned?” The Listener, April 27, 1978, pp. 526-28.

Milton Friedman, "Inertia and the Fed,” Newsweek, July 24, 1978, p. 70.

Associated Press, "Conservatives Draft Plan to Control Taxes, Inflation," Evening Capital (Maryland),

November 18, 1978, p. 2.

"Economic Outlook,” Midland Bank Review (U.K.), Summer 1979, pp. 1-4.

Milton Friedman, “Why Inflation Is Like Alcoholism,” The Listener, April 24, 1980, pp. 521-22.

R.J. Ball, “Unemployment and Keynesian Policies,” Financial Times, February 4, 1981, p. 15.

Michael Field, “Selling Friedman’s Miracle Cure,” Evening Post, April 27, 1981, p. 2.

Walter Guzzardi, Jr., “The Dire Warnings of Milton Friedman,” Fortune, March 19, 1984, pp. 28-34 of U.S. edition; pp. 20-26 of international edition.

Maximilian Walsh, “The Tail That Wags the Dog,” Sydney Morning Herald, October 9, 1986, p. 17.

Milton Friedman, “Monetary History, Not Dogma,” Wall Street Journal, February 12, 1987, p. 24.

Daniel Doron and Steven Plaut, “Liberalization: ‘Israel Didn’t Go Far Enough,’” Jerusalem Post,

November 6, 1987.

Milton Friedman, “Fed’s Arsenal Has Only One Big Gun,” Wall Street Journal, April 5, 1990, p. 19.

Peter Jay, "Problems with the Virtuous Circle," The Independent (London), September 23, 1991, p. 21.

Milton Friedman, “Once Again: Why Socialism Won’t Work,” New York Times, August 13, 1994, p. 21.

Brian Doherty, "Best of Both Worlds: Interview with Milton Friedman,” Reason, June 1995.

“Milton Friedman on Hong Kong’s Future,” Wall Street Journal, February 12, 1997, p. A16.

Milton Friedman, “Asian Values: Right...,” National Review, December 31, 1997, pp. 36-37. 


\section{Nelson}

Robert J. Samuelson, “The Age of Friedman,” Newsweek, June 15, 1998, pp. 30-31.

Philip Thornton, "Friedman Condemns the Single Currency as a 'Grave Error,'” The Independent, August 28, 2001, p. 11.

David Isaac, “To Keep U.S. Economy Growing, Curb Government, Take Risks: Friedman,” Investor’s Business Daily, April 15, 2004, pp. A1 and A8.

\section{Television Programs Cited}

Friedman appearance on Meet the Press, October 24, 1976, NBC transcript.

Friedman appearance on Newsday, BBC2, November 9, 1976; BBC transcript.

Friedman appearance on segment "Will There Always Be an England?” 60 Minutes, November 28, 1976 , CBS transcript.

Friedman appearance on Panorama, BBC1, December 6, 1976; BBC transcript.

Friedman appearance on Meet the Press, November 12, 1978; NBC transcript.

Friedman appearance on Newsweek (BBC television program) episode entitled "New Tory Economics," October 11, 1979; excerpted on Pandora's Box (episode title "The League of Gentlemen”), BBC2, June 25, 1992 (also screened by ABC television, Australia, on August 10, 1992, on program Four Corners, with episode title "From Keynes to Chaos"); BBC transcript.

Free to Choose, U.S. series, PBS, 1980; shows and transcripts available online.

Free to Choose, U.K. series, broadcast BBC2 February and March 1980; BBC transcripts.

Friedman interview with Brian Lamb, C-SPAN, November 20, 1994; transcript available on C-SPAN website.

Friedman talk, April 16, 1996, at Claremont College, broadcast on C-SPAN on December 26, 1996. Excerpts transcribed by author from off-air audio recording.

House of Commons Debates, April 15, 1969, and November 30, 1976.

House of Commons (various years). Parliamentary Debates. London: HMSO.

Milton Friedman Speaks, 1980 video and transcript releases of lecture series delivered in 1977 and 1978; also released as Idea Channel DVD series. 